ASSESSING THE ENERGY-EFFICIENCY GAP

Todd D. Gerarden

Richard G. Newell

Robert N. Stavins

WORKING PAPER 20904 
NBER WORKING PAPER SERIES

\title{
ASSESSING THE ENERGY-EFFICIENCY GAP
}

\author{
Todd D. Gerarden \\ Richard G. Newell \\ Robert N. Stavins \\ Working Paper 20904 \\ http://www.nber.org/papers/w20904
NATIONAL BUREAU OF ECONOMIC RESEARCH
1050 Massachusetts Avenue
Cambridge, MA 02138
January 2015

This paper draws, in part, on a workshop held at Harvard, October 24-25, 2013, "Evaluating the Energy-Efficiency Gap," co-sponsored by the Duke University Energy Initiative and the Harvard Environmental Economics Program. The workshop's agenda is provided in Appendix 1, and the list of participants in Appendix 2. We are very grateful to all of the participants for the insights they provided on the questions addressed at the workshop. In addition, we gratefully acknowledge valuable comments on a previous version of the manuscript by Robert Stowe, editorial contributions by Marika Tatsutani, and generous financial support from the Alfred P. Sloan Foundation. The authors, however, are fully responsible for any errors and all opinions expressed in this paper. The views expressed herein are those of the authors and do not necessarily reflect the views of the National Bureau of Economic Research.

NBER working papers are circulated for discussion and comment purposes. They have not been peerreviewed or been subject to the review by the NBER Board of Directors that accompanies official NBER publications.

(C) 2015 by Todd D. Gerarden, Richard G. Newell, and Robert N. Stavins. All rights reserved. Short sections of text, not to exceed two paragraphs, may be quoted without explicit permission provided that full credit, including (C) notice, is given to the source. 
Assessing the Energy-Efficiency Gap

Todd D. Gerarden, Richard G. Newell, and Robert N. Stavins

NBER Working Paper No. 20904

January 2015

JEL No. L00,Q4,Q48,Q5

\begin{abstract}
Energy-efficient technologies offer considerable promise for reducing the financial costs and environmental damages associated with energy use, but these technologies appear not to be adopted by consumers and businesses to the degree that would apparently be justified, even on a purely financial basis. We present two complementary frameworks for understanding this so-called "energy paradox" or "energyefficiency gap." First, we build on the previous literature by dividing potential explanations for the energy-efficiency gap into three categories: market failures, behavioral anomalies, and model and measurement errors. Second, we posit that it is useful to think in terms of the fundamental elements of cost-minimizing energy-efficiency decisions. This provides a decomposition that organizes thinking around four questions. First, are product offerings and pricing economically efficient? Second, are energy operating costs inefficiently priced and/or understood? Third, are product choices costminimizing in present value terms? Fourth, do other costs inhibit more energy-efficient decisions? We review empirical evidence on these questions, with an emphasis on recent advances, and offer suggestions for future research.
\end{abstract}

Todd D. Gerarden

Harvard University

gerarden@fas.harvard.edu

Richard G. Newell

Nicholas School of the Environment

Duke University

Box 90227

Durham, NC 27708

and NBER

richard.newell@duke.edu
Robert N. Stavins

JFK School of Government

Harvard University

79 JFK Street

Cambridge, MA 02138

and NBER

robert_stavins@hks.harvard.edu 


\title{
ASSESSING THE ENERGY-EFFICIENCY GAP
}

\author{
Richard G. Newell, Robert N. Stavins, and Todd D. Gerarden ${ }^{1}$
}

\section{INTRODUCTION}

Global energy consumption is on a path to grow 30-50 percent over the next 25 years, bringing with it, in many countries, increased local air pollution, greenhouse gas emissions, and oil consumption-and higher energy prices. Energy-efficient technologies offer considerable promise for reducing the costs and environmental damages associated with energy use, but these technologies appear not to be used by consumers and businesses to the degree that would apparently be justified, even on the basis of their own (private) financial net benefits. Our purpose is to advance understanding of this "energy paradox" or "energy-efficiency gap."

We define the "energy paradox" as the apparent reality that some energy-efficiency technologies that would pay off for adopters are nevertheless not adopted. This basic definition relates to the issue of private optimality. We define the "energy-efficiency gap" as the apparent reality that some energy-efficiency technologies that would be socially efficient are not adopted. This broader concept relates to social optimality.

Adoption of energy-efficient technologies could reap both private and social rewards, in the form of economic, environmental, and other social benefits from reduced energy consumption. In response, governments and firms around the world have adopted policies to increase energy efficiency and capture these benefits. Still, there is a broadly held view that various barriers to the adoption of energy-efficient technologies have prevented the realization of a substantial portion of these benefits.

Gerarden is a Ph.D. student in Public Policy at Harvard University; Newell is the Gendell Professor of Energy and Environmental Economics at the Nicholas School of the Environment, Duke University, Research Associate of the National Bureau of Economic Research, and University Fellow of Resources for the Future; and Stavins is the Albert Pratt Professor of Business and Government at the Harvard Kennedy School, Research Associate of the National Bureau of Economic Research, and University Fellow of Resources for the Future. This paper draws, in part, on a workshop held at Harvard, October 24-25, 2013, "Evaluating the Energy-Efficiency Gap," co-sponsored by the Duke University Energy Initiative and the Harvard Environmental Economics Program. The workshop's agenda is provided in Appendix 1, and the list of participants in Appendix 2. We are very grateful to all of the participants for the insights they provided on the questions addressed at the workshop. In addition, we gratefully acknowledge valuable comments on a previous version of the manuscript by Robert Stowe, editorial contributions by Marika Tatsutani, and generous financial support from the Alfred P. Sloan Foundation. The authors, however, are fully responsible for any errors and all opinions expressed in this paper. 
Over the last several decades, a number of scholars have observed that cost-effective energyconservation technologies appear to diffuse at suboptimal rates. Shama $(1983)^{2}$ and subsequently the U.S. Department of Energy (1991) noted the paradoxically slow rate of penetration of various energy-conservation technologies, and Jaffe and Stavins (1994a) provided a conceptual framework for thinking about possible explanations (Figure 1).

Why do decision makers underinvest-or at least appear to underinvest-in energy-efficient technologies, relative to the predictions of some engineering and economic models? Explanations for the paradox and gap tend to fall into three broad categories: (1) market failures, (2) behavioral effects, and (3) modeling flaws.

Potential market-failure explanations include: information problems (such as principal-agent issues affecting decisions about the adoption of energy-efficiency technologies in renter-occupied commercial and residential properties, and asymmetric information); energy market failures (including environmental and national security externalities, and average-cost electricity pricing); capital market failures (such as liquidity constraints); and innovation market failures (such as information spillovers from research and development). Potential behavioral explanations include: inattentiveness and salience issues; myopia and short sightedness; bounded rationality and heuristic decision-making; prospect theory and reference-point phenomena; and systematically biased beliefs.

Despite this extensive set of posited explanations for the energy paradox and the energyefficiency gap, there are also reasons to believe that the observed rate of diffusion of energysaving technology may not be as paradoxical as it may at first appear. Evidence for the energy paradox typically involves assumptions about the economic costs and energy use of alternative product choices, the usage profile and characteristics of consumers, and the interaction among these factors. Predictions founded on incorrect assumptions could misstate the size of the energyefficiency gap. Hence, we characterize a third category of potential explanations as model and measurement explanations. These include unobserved or understated costs of adoption; ignored product attributes; heterogeneity in benefits and costs of adoption across potential adopters; use of incorrect discount rates; and uncertainty, irreversibility, and option value.

Determining the validity of each of these explanations - and the degree to which each contributes to the energy-efficiency gap-are crucial steps in crafting effective public policy responses and in understanding the likely net benefits of such policies. Likewise, firms may identify different internal policies or marketing strategies in response to each explanation. Our hope is that this paper can help inform future research and policy by synthesizing past work and identifying key gaps in knowledge.

2 All references may be viewed and downloaded from an online bibliographic library available to the public: www.zotero.org/groups/ energy efficiency gap. 
In the context of Schumpeter's classic trio of invention, innovation, and diffusion, our investigation focuses primarily-but not exclusively-on the diffusion (adoption) of energyefficiency technologies. ${ }^{3}$ To provide structure to the many economic elements that enter into adoption decisions related to energy efficiency, we find it useful in our review and synthesis to think in terms of the fundamental elements of cost-minimizing energy-efficiency decisions. This decomposition is deliberately simple in order to highlight the main features of the issue, and does not explicitly account for all of the factors we consider in our analysis, such as uncertainty, the dynamic nature of decisions (and resulting option value), and heterogeneity:

$$
\underbrace{\min \text { Total Cost }}_{\text {objective }}=\underbrace{K(E)}_{\text {equipment purchase cost }}+\underbrace{O\left(E, P_{E}\right) \times D(r, T)}_{\text {discounted operating costs }}+\text { other costs }
$$

Where $K(E) \quad$ = equipment purchase cost;

$$
\begin{array}{ll}
E & =\text { annual energy use; } \\
O\left(E, P_{E}\right) & =\text { annual operating cost; } \\
P_{E} & =\text { price of energy; } \\
D(r, T) & =\text { present value factor; } \\
r & =\text { discount rate; and } \\
T & =\text { time horizon. }
\end{array}
$$

Based on this decomposition of cost-minimizing energy-efficiency adoption decisions, we organize our assessment in the form of four fundamental questions (and a total of 23 sub-questions, with each sub-question phrased so that an affirmative answer suggests that the respective factor contributes to the energy-efficiency gap). Referring to the first term of the above equation, we ask whether product offerings and pricing are economically efficient. This question is examined in section 2 of the paper. Then, in section 3 of the paper, we ask whether energy operating costs are inefficiently priced and/or understood. Next, in section 4, referring to the entire equation, we ask whether product choices are cost-minimizing in present value terms. Finally, in section 5 of the paper, we focus on the final term in the above equation and ask whether other costs inhibit more energy-efficient decisions. Alternative explanations of the paradox and gap become parts of sub-questions in these four sections of the paper. In section 6, we offer our conclusions and suggestions for future research priorities. 


\section{ARE THE ENERGY-EFFICIENCY AND ASSOCIATED PRICING OF PRODUCTS ON THE MARKET ECONOMICALLY EFFICIENT?}

One set of possible explanations for the energy-efficiency gap is related to the potential economic inefficiencies associated with the first element of the cost-minimization framework presented above-namely, the variety of energy-efficient products on the market, their energy-efficiency levels, and their pricing. Although the theory is clear, empirical evidence is-in general —very limited. Going forward, more data that could facilitate potential future empirical research are becoming available, although firm-level data are less available for research purposes than data on consumer decision-making.

Given the range of existing public policies in this realm (such as minimum energy-efficiency standards, labeling and other information policies, utility demand-side management programs, and public funding of research), it is unclear whether there are issues related to the variety, availability, and pricing of energy-efficient products, as distinct from many other types of products. Partly because of this, we do not see this area as meriting a high priority for future research, with the exception of empirical research on whether consumers have adequate information regarding energy-efficient products. Given the many policies and programs in place that are intended to improve consumer information on energy efficiency, research could be usefully directed toward evaluating and improving the effectiveness and efficiency of current information policies.

\subsection{Are there too few energy-efficient alternatives, is their energy efficiency too low, or are they priced too high due to market power?}

It is certainly conceivable that the socially optimal diversity of products may not be offered on the market. This could be due to the presence of fixed costs and monopolistic competition. Two forces contribute to this outcome. First, not all welfare-improving products are offered if firms are unable to capture the consumer surplus associated with a given product due to the difficulty of perfect price discrimination. Second, firms introducing a new product may not internalize the impact of their product's entry on other firms' profits, which can then lead to too many products on the market. ${ }^{4}$ Despite the soundness of this theory, there is no empirical evidence on the effect of these factors in the energy-efficiency domain.

Economists generally consider energy-efficient products to be of higher quality than less efficient but otherwise comparable products. The theory of vertical differentiation suggests that for a single product offering, firms will undersupply product quality (including energy efficiency) relative to 
the social optimum if the marginal consumer values efficiency less than the average consumer. Firms respond to marginal quality valuation, while the social optimum is achieved by setting quality according to average quality valuation (Spence 1975, 419). ${ }^{5}$ However, in the case of multiproduct firms, theory does not provide clear guidance on quality distortion. Indeed, for any given product, the anticipated effect is ambiguous: a firm could supply too much or too little energy efficiency relative to the social optimum, due to demand interactions with the firm's other products.

Calibrations of a theoretical model of the automobile market suggest multi-product manufacturers would consider these interactions when choosing fuel economy for each vehicle (Fischer 2010, 5-8), but manufacturers may over- or under-supply energy efficiency in different products in response to heterogeneity in consumer valuation of fuel economy. This is reminiscent of quality distortion arising in models of price discrimination: manufacturers provide too much fuel economy in vehicle classes demanded by consumers who value fuel economy highly, and too little fuel economy in vehicle classes demanded by consumers who value fuel economy less. This allows manufacturers to extract surplus from consumers according to consumers' tastes, while reducing the likelihood that consumers defect to other vehicle classes. But theory does not offer clear predictions about welfare impacts, and empirical analysis is lacking in the energy-efficiency context.

Limited empirical research on automobiles has explored the responsiveness of suppliers to changes in energy costs. Automobile manufacturers appear to respond to short-run fluctuations in fuel prices by offering cash incentives (Langer and Miller 2012), but the responsiveness of product offerings to long-run trends in energy prices is much less clear, partly because it is confounded by simultaneous policy mandates for fuel economy.

Changes in market structure can also affect producer incentives, but anticipated effects on product variety are ambiguous. In the case of firm mergers, the ambiguity is due to countervailing forces of cost reduction, leading to lower prices; and reduced competition, leading to higher prices (S. T. Berry and Waldfogel 2001). Changes in the demand side of the market can also affect product quality and variety. In particular, variation in market size can alter incentives for suppliers, leading to changes in the variety and quality of products available. ${ }^{6}$

Public policies may also interact with and influence energy-efficient product market offerings, possibly in unanticipated ways. Recent empirical evidence from the appliance industry suggests (Spence 1975).

6 If increases in product quality require an increase in fixed costs, the highest quality offered will increase with market size, while the market will remain concentrated (Shaked and Sutton 1987, 133-140). 
that firms employ the Energy Star logo as a price discrimination tool, as some consumers have a high willingness to pay for this certification. This allows firms to extract surplus from consumers, and may have distributional impacts that were not widely anticipated (Houde 2014b). Another example of unanticipated consequences is found in the response of automobile manufacturers to the "notched" Gas Guzzler Tax, which distorts manufacturer incentives and is less efficient than a smooth linear tax (Sallee and Slemrod 2012). ${ }^{7}$

There exists a tension between optimal innovation and product offerings, on the one hand, and optimal adoption of energy-efficient products, on the other hand. Firms incur fixed costs to generate energy-efficiency improvements in products, and firms may not invest if they do not expect to recover these costs. However, theory suggests that products offering significant reductions in energy consumption at low cost would be adopted quickly and widely, a process that could be hampered by innovators charging above marginal cost to recoup fixed costs. Optimal policy would seek to balance these two forces to encourage both innovation and adoption of energy-efficient products (Kamien and Schwartz 1982, 30-31).

This tension, as with much of the preceding discussion, is generic; that is, the issues are not specific to energy efficiency. In other domains, research and development subsidies and intellectual property protections are the primary tools used to encourage innovation, while anti-trust regulation is intended to ameliorate problems associated with market concentration. There is no existing evidence to suggest that energy-efficiency markets exhibit particular market failures that point to tools beyond these traditional innovation and antitrust policies.

The limitations of theoretical results and the small amount of empirical evidence in this realm are striking. While empirical evidence from some sectors generally supports the theoretical findings, ${ }^{8}$ the relevance for energy efficiency is unclear. Hence, empirical analysis will be needed to assess the role of these factors for energy-efficient product markets. In particular, empirical research with structural models is needed to understand and predict impacts of energy efficiency policy, particularly in industries that are highly concentrated and highly regulated.

\footnotetext{
7 This comparison of notched and smooth taxes hinges on the assumption of consumer rationality. Under alternative assumptions (see below), the choice between notched and smooth policies becomes considerably less clear. For example, the benefits of certifications may outweigh these supply distortions if consumers are inattentive to energy efficiency (Sallee 2013, 32).

8 For example, in the restaurant industry, increasing market size is associated with lower concentration, greater variety, and more quality differentiation. In the newspaper industry, where improving quality requires higher fixed costs, larger markets remain concentrated and average quality improves (S. T. Berry and Waldfogel 2010).
} 


\subsection{Are there too few new energy-efficient product offerings due to demand spillovers?}

Product offerings may be sub-optimal in number due to demand spillovers. A firm introducing a new, relatively unknown product will sometimes incur large fixed costs. This is because product innovations may exhibit an information asymmetry between consumers and producers. Hence, consumers must be convinced to try a new product. Firms try to generate demand with advertising and/or promotional pricing, the cost of which must be recouped through sales. The consequent learning by consumers can spill over to other consumers, producing positive externalities that benefit the innovating firm. Importantly, however, the firm's competitors can also capture these demand spillovers-without paying the costs to educate consumers. The net effect of these two forces is ambiguous. If the latter effect dominates, firms will introduce too few new products.

Existing research provides little insight into the contributions of such demand spillovers to the energy-efficiency gap. Hybrid vehicles are a rare example of an energy-efficient technology that has been well studied and that may be associated with learning spillovers among consumers. Empirical evidence that market penetration rates of hybrid vehicles affect future purchases is consistent with this hypothesis. Furthermore, these learning spillovers may not be fully appropriated by the original producer; higher penetration rates for the Toyota Prius lead to greater purchases of hybrids of all makes (Heutel and Muehlegger 2014, 3). ${ }^{9}$

The impact of demand spillovers on product offerings is inherently difficult to study, because researchers do not observe potentially innovative energy-efficient products that firms decide not to introduce. In the absence of such data, researchers can study the impact of learning spillovers across products that are introduced, which can serve as a guide for whether these spillovers appear to be significant enough to prevent the introduction of candidate products. Such research could follow the approach of research on the pharmaceutical industry (Crawford and Shum 2005; Coscelli and Shum 2004; Berndt, Pindyck, and Azoulay 2003). ${ }^{10}$ The existence and magnitude of spillovers across products appears to be correlated with the degree of substitutability of the products (Janakiraman, Sismeiro, and Dutta 2009). This finding accords with theory and provides a useful guide for evaluating the importance of learning spillovers among energy-efficient products. Implementing government or utility programs that educate consumers about innovative energysaving technologies is one possible response to significant demand spillovers.

Of course, just as learning spillovers can increase demand for similar products, such spillovers can also dampen demand. Heutel and Muehlegger (2014) find that higher market penetration by the Honda Insight led to fewer purchases of all hybrid models, consistent with anecdotal evidence that the Insight was of lower quality.

10 Research in pharmaceuticals examines both competition between branded and generic drugs following patent expiration, and competition among branded drugs. The latter is more relevant to energy-efficient technologies. 


\subsection{Does adverse selection due to asymmetric information inhibit energy- efficient product offerings?}

In theory, asymmetric information could lead to adverse selection in the marketplace, which could in turn lead to underinvestment in energy efficiency. Such underinvestment could occur if buyers cannot perfectly observe the energy efficiency of products, and as a result are not willing to pay for its true expected value. If sellers have private information they cannot credibly communicate, some energy-efficient products may not be offered in the market (Akerlof 1970, 489-490). This problem of asymmetric information is potentially more pronounced in the secondary market, as consumers who invest in energy-efficient capital, such as home weatherization, may have difficulty capitalizing on these investments when reselling. Asymmetric information is sometimes cited as a justification for disclosure policies and standards—such as energy-efficiency testing and labels. ${ }^{11}$

Despite widespread acceptance of the theoretical argument for adverse selection due to information asymmetries, there is little empirical evidence of this phenomenon in the context of energy efficiency, particularly in the period since energy-efficiency product testing and labeling became the norm for many energy-using appliances. Empirical research on the effects of asymmetric information is more prevalent in contexts unrelated to energy efficiency. These studies provide only limited guidance for two reasons. First, their results are mixed ${ }^{12}$ and second, the characteristics of these markets are different from those of energy-efficiency markets.

By its very nature, this problem is difficult to study. Like the uninformed buyer, researchers are often unable to observe perfectly the energy-efficiency characteristics of a product. Unobserved heterogeneity among buyers and sellers, particularly in buyers' demand functions, complicates analysis. However, theory does provide some qualitative guidance for policy and research efforts. Outcomes depend on disclosure technology; in markets where disclosure is low-cost and effective, there may be less rationale for policy intervention. ${ }^{13}$

For example, the U.S. government cited asymmetric information as a justification for its recent medium- and heavy-duty vehicle fuel economy standards, projecting that these standards will save industry money after accounting for both upfront costs and fuel savings (U.S. Environmental Protection Agency and U.S. National Highway Traffic Safety Administration 2011, 57315-57325).

12 For example, evidence from insurance markets both supports (Cohen 2005; Finkelstein and Poterba 2004) and undermines (Chiappori and Salanie 2000; Cardon and Hendel 2001) the hypothesis of asymmetric information. Testing with data from insurance markets is difficult. See Chiappori, et al. (2006) and Finkelstein and Poterba (2006) for discussions of the tests used in empirical work.

13 See Jovanovic (1982) for an analysis of how disclosure costs affect welfare. Recent empirical evidence on the impact of disclosure costs on equilibrium prices comes from online automobile sales (Lewis 2011). Several companies have recently faced sanctions by the U.S. Department of Energy (DOE) for overstating the efficiency of their products, failing to meet minimum efficiency standards, or both. 


\subsection{Do product developers invest too little in energy efficiency due to technology spillovers via research and development and learning-by-doing?}

Spillovers in the energy-efficiency innovation process can contribute to the energy-efficiency gap if they lead to underinvestment in the development of new energy-efficient innovations. These spillovers are possible both in basic research and development (R\&D) and in subsequent commercialization.

R\&D spillovers. In theory, firms will invest too little effort in research when the resulting knowledge benefits not only them, but other firms as well. A firm does not reap the full rewards of its investment when knowledge is nonappropriable. This effect is probably most pronounced for early stages of research, because firms cannot capture the knowledge generated in the process perfectly, whereas firms can reduce spillovers in later stages of research through intellectual property protections (Nordhaus 2011, 667).

There is no direct empirical evidence of R\&D spillovers associated with energy efficiency, ${ }^{14}$ but there is substantial evidence of these spillovers in other industries, with empirical estimates of such spillovers ranging from close to zero percent to 100 percent, with most estimates between 20 and 50 percent (Griliches 1992, S43; B. H. Hall, Mairesse, and Mohnen 2010, 1070-1).

Many countries have policies to address generic R\&D spillovers. Research grants are widely used to encourage basic research, and tax incentives are used to encourage applied R\&D. In addition, intellectual property protections ameliorate the problem of nonappropriability for innovations at the stage of commercialization.

Learning-by-doing spillovers. Learning-by-doing (LBD) refers to productivity improvements that come with experience. The learning effect can be so strong that firms may be willing to operate at a loss when manufacturing a new product to improve productivity and become more competitive (Benkard 2004). But knowledge from such learning can spill over to other firms, creating a freerider problem. Firms may then underinvest or delay investment to capture knowledge from other firms, rather than incur the cost of generating the knowledge themselves (Arrow 1962; Spence 1981).

Empirical evidence suggests LBD spillovers are present in many industries, with learning spilling over even to firms that are separated by space and national borders (Lieberman 1984, 214; Irwin and Klenow 1994, 1215-1219), although other research suggests that while learning spillovers

14 Although Popp (2002) uses patent classifications to identify various alternative-energy and energy-efficiency technologies and estimates the elasticity of energy-patenting activity with respect to energy prices for these technologies, he does not investigate the degree of spillovers. 
within a firm can be significant, learning spillovers across firms can be small (Thornton and Thompson 2001, 1356-1363).

There is no direct empirical evidence of LBD in energy efficiency, and none about the extent of any learning spillovers. In contrast to the case of R\&D spillovers, it appears unlikely that LBD spillovers are a significant contributor to the energy-efficiency gap. One possible route for research would be to study the engineering pathways by which LBD spillovers occur, building on recent efforts to understand LBD mechanisms (Levitt, List, and Syverson 2013) and utilizing plant-level production data and dynamic structural models of firm production functions.

\subsection{Do consumers have inadequate information regarding energy-efficient products?}

Lack of information could lead to private decisions to invest in energy-efficient technologies less than would otherwise be the case, ${ }^{15}$ and such lack of information is one of the most commonlycited justifications for policy intervention in this realm (Palmer et al. 2013, 272; Sanstad, Hanemann, and Auffhammer 2006, 6-9). Information provision has been documented to affect consumer decisions. In recent field experiments, provision of information about personal energy use with peer comparisons has resulted in immediate and, to some degree, persistent reductions in energy use (Allcott 2011a; Costa and Kahn 2013; Ayres, Raseman, and Shih 2013; Allcott and Rogers 2014).

However, few studies disentangle the effects of information provision from competing explanations of consumer behavior. One recent study attempts to do this using a stated choice experiment to understand the relative importance of various elements of information labels-including the EnergyGuide, Energy Star, and European-Union (EU)-style labels_-while controlling for other relevant factors, such as discounting behavior (Newell and Siikamäki 2014). This research finds that a lack of relevant information can lead to significant undervaluation of energy efficiency and that providing simple information on the economic value of saving energy was the most important element guiding more cost-effective energy-efficiency decisions.

Past evidence in the United States and recent evidence from India suggests that imperfect information also exists among firms (as consumers of energy-efficiency technology), and that firms may fail to undertake profitable investments because they are unaware of them ( $\mathrm{S}$. T. Anderson and Newell 2004; Bloom et al. 2013). Anderson and Newell (2004) examine industrial energy audits and find that while plants accept only half of recommended projects, most plants respond 
to the costs and benefits presented in energy audits and, with the additional information, adopt investments that meet hurdle rates consistent with standard investment criteria.

In theory and in practice, an informed third party can fill the information gap, as many government and private labeling programs seek to do. Examples include EnergyGuide labels, Energy Star logos, automobile fuel economy labels, and LEED certification. ${ }^{16}$ A number of studies have analyzed the effect of such information policies. For example, Sallee (2013) highlights the possible supply distortions caused by coarse energy-efficiency certifications, such as the binary certification employed in the Energy Star program. But the benefits of coarse certifications may outweigh supply distortions, given limits on consumer attention to detail about performance. Houde (2014a) evaluated the welfare effects of the Energy Star certification program and found that consumers rely heavily on the certification, indicating that the program does provide new information to the market. However, he also found that some consumers over-rely on the binary label, as opposed to considering actual energy savings. This induces suppliers to bunch at the certification point and could crowd out efficiency investments (Houde 2014b).

In the case of residential energy consultations, few households seek the information, even when it is subsidized, and even fewer act upon the information (Tonn and Berry 1986, 785; L. G. Berry 1993, 54). However, hedonic analysis of two building certifications, LEED and Energy Star, suggest that certifications provide information to the market, as certification status explains some of the residual variation in rental and sales prices after conditioning on prominent property characteristics (Eichholtz, Kok, and Quigley 2010, 2012). Residential certifications are associated with higher sales prices in both the Netherlands and the United States (Brounen and Kok 2011; Walls, Palmer, and Gerarden 2013). The U.S. government provides information on appliance efficiency via Energy Star certifications, which some consumers rely on too heavily (Houde 2014a, 3), highlighting a tension between benefits from salient, simple certifications and more complex information provision.

Experimental research on point-of-sale interventions for energy-consuming products has found heterogeneity in consumer beliefs about possible energy-cost savings. Providing information to consumers could, in theory, lead some consumers to increase energy use-or investment in inefficient technology-in response to information, in a mean-reverting pattern. Carefullydesigned information provision may eliminate this effect (Schultz et al. 2007, 432).

Further research is needed to distinguish the effects of incomplete information from competing explanations of the energy-efficiency gap, such as inattention and heuristic decision-making. Randomized control trials, including both revealed and stated choice experiments, may be the most promising method to isolate and test these mechanisms. Likewise, targeted, randomized research 
designs could provide practical guidance for existing and potential new policy interventions. In particular, research on the effects of online information provision is merited, because consumers increasingly obtain information about and purchase energy-consuming (and other) products online.

\section{ARE ENERGY OPERATING COSTS INEFFICIENTLY PRICED AND/OR UNDERSTOOD?}

Even if consumers make privately optimal decisions, there are a number of reasons why energysaving technology may diffuse more slowly than the socially optimal rate, as energy production and consumption generate a number of negative externalities. In other words, even if the energy paradox is not present, the energy-efficiency gap may nevertheless exist. For example, the combustion of fossil fuels is associated with numerous environmental pollutants, including greenhouse gases, sulfur dioxide, oxides of nitrogen, and particulate matter, and the environmental and human health effects of these pollutants are not fully incorporated into the price of fossil fuels (and electricity generation). Such unpriced externalities and/or utility regulation can, in principle, lead to a divergence between the energy prices consumers face and the prices that would guide efficient decisions.

As in the previously examined realm, the theoretical arguments in this area are robust. However, unlike in the previous case, here the empirical evidence is considerable, and in some cases quite convincing. In most cases, data are likely to be available for additional research, with the exception of those sub-questions below (3.4 and 3.5) that refer to beliefs, which are challenging to recover with a sufficient degree of reliability. Furthermore, in several cases, existing policies (e.g., gasoline taxes, carbon pricing, electricity price structures) appear not to provide sufficient incentives for energy efficiency from an economic perspective, suggesting that further research is warranted. Indeed, we would ascribe relatively high priority to the pursuit of further research in this realm.

\subsection{Are gasoline prices too low due to unpriced externalities?}

Some unpriced transportation-related externalities are a direct function of gasoline consumption. These include the effects of greenhouse gas emissions and oil dependency (National Research Council 2010, 333). Available estimates place these external costs at about 30-40 cents per gallon (Parry, Walls, and Harrington 2007, 384.). Local pollution, congestion, and accident externalities can be approximated as mileage-related costs, and converted to per gallon costs; estimates for these are as great as $\$ 2.40$ per gallon (Parry, Walls, and Harrington 2007, 384; M. L. Anderson and Auffhammer 2013). These externality estimates are more than six times larger than current gasoline taxes in the United States. ${ }^{17}$ 
Raising gasoline prices (whether through taxation or otherwise ${ }^{18}$ ) is not necessarily the optimal policy response to all of these externalities. For example, the marginal damages created by congestion are both location- and time-dependent and would optimally be priced accordingly. Accident externalities may be best regulated by weight-specific mileage taxes, although empirical evidence suggests that a simpler gasoline tax could approximate a weight-specific mileage tax (M. L. Anderson and Auffhammer 2013).

Competing goals present another complication. Due to the rebound effect, improvements in energy efficiency could lead to more vehicle miles traveled, resulting in larger external costs due to congestion and accidents. Addressing congestion and accidents through gasoline taxes would provide an incentive for energy-efficiency improvements to vehicles, but would fail to satisfy economic efficiency due to interactions with other externalities.

On net, economists agree that the price of gasoline in the United States is inefficiently low, and that this contributes to the divergence between observed and socially optimal adoption of energyefficient technology.

\subsection{Are electricity prices too low due to unpriced externalities?}

Electric power production is also associated with environmental externalities, which distort electricity generation costs downward, driving a wedge between privately and socially optimal rates of technology adoption. Quantitative estimates of the magnitude of these externalities are limited, and most do not account for marginal emissions and damages being both location-and time-specific (Muller and Mendelsohn 2009; Zivin, Kotchen, and Mansur 2012; Cullen 2013).

Coal and natural gas combustion for electric power production have received the most attention, with estimates suggesting the (non-carbon) damages from coal-powered electricity cost society about 3 to 4 cents per kilowatt-hour (kWh), and those from natural gas-powered electricity cost society much less than 1 cent per $\mathrm{kWh}$ on average (National Research Council 2010, 149). Carbon dioxide emissions from these sources approximately double these cost estimates, depending on choices of the social cost of carbon and discount rate. ${ }^{19}$

In some countries, fuel prices may be too low due to subsidization. Global fuel subsidies comprised 0.7 percent of global Gross Domestic Product in 2011 (IMF 2013).

Presentation of preliminary research results at the October 2013 workshop hosted by the Harvard Environmental Economics Program, and subsequent communication. Other fuel sources (for example, nuclear and renewable energy) and stages of production (for example, fuel extraction) produce externalities that are more difficult to quantify but also potentially important. Qualitative discussions of these impacts exist, but there is little knowledge of the economic magnitudes of the externalities. See, for example, National Research Council (2010, 64-153). Table 2-2 on page 70 summarizes the discussion. 
In general, the full incorporation of environmental externalities into the price of electricity would likely raise electricity prices in most U.S. regions. However, many of these externalities are already regulated and thereby indirectly_ and sometimes directly_ priced. But other market distortionssuch as electricity price regulation-make it difficult to judge overall whether electricity prices are too low, and the answer seems certain to vary by region (and time of day). More research is needed to quantify and monetize electricity generation externalities, including comprehensive assessments of which externalities are currently unpriced or underpriced and which are effectively addressed by existing policy.

\subsection{Are retail electricity or natural gas prices too low (or high) due to regulation?}

Evidence is mixed regarding whether the regulation of electricity and natural gas prices partly explains the energy-efficiency gap, due to regulated prices falling below marginal generation costs. On the one hand, the presence of average-cost pricing and lack of time-varying pricing suggests that prices are too low, but several features of electricity and gas price regulation work in the opposite direction, toward prices that exceed marginal cost.

Important dynamics in electricity markets may cause prices to be too low, particularly during peak load periods. The marginal cost of electricity generation varies over time and many existing pricing schemes do not reflect this variation, leading to inefficient utilization decisions (Joskow and Wolfram 2012, 381). Real-time electricity pricing could correct these incentive problems, particularly if consumers have access to real-time feedback on consumption (Jessoe and Rapson 2014), which could yield large efficiency gains (Borenstein 2005, 93). But the impact of time-ofuse pricing and associated load shifting on investment in energy-efficient technology is ambiguous (Gillingham, Newell, and Palmer 2009, 605).

On the other hand, many utilities use two-part tariffs to facilitate the recovery of system fixed costs while preserving marginal incentives (Coase 1946, 173-174). These tariffs are not set optimally. Typically, marginal (or usage) prices are set above marginal costs to recover fixed costs. For example, U.S. retail natural gas customers face prices inclusive of fixed distribution costs that are well above marginal cost, with one study estimating that these additional costs are comparable to a tax of over $\$ 50$ per ton of carbon dioxide (Davis and Muehlegger 2010). Other evidence from the electricity sector supports the presence of pricing above marginal cost (Naughton 1986, 411). ${ }^{20}$

A second possible reason for inefficiently high prices of energy for regulated utilities comes from the principal-agent problem that regulated utilities may not minimize capital costs on behalf 
of consumers, and these costs cannot be perfectly observed by regulators. Under rate-of-return regulation, utilities may overcapitalize in order to increase profits (Averch and Johnson 1962). This has been confirmed empirically in the context of regulated electric utilities (Spann 1974, 50). Comparisons of electricity generators subject to different regulatory regimes following deregulation in the United States also support this phenomenon (Fowlie 2010, 863; Cicala 2014, 2).

However, other research does not support the theory that utilities overinvest to increase profits (Boyes 1976), and recasting this problem in a dynamic framework highlights the possibility of regulatory hold-up (Gilbert and Newbery 1994). There is empirical evidence that, due to regulatory hold-up, utilities underinvest in infrastructure that improves reliability (Lim and Yurukoglu 2014); this could lead to inefficiently low prices.

Inattention, rational or otherwise, may also influence consumer decisions. Recent empirical research provides evidence that retail electricity customers respond to average price rather than marginal price (Ito 2014), and that feedback about electricity consumption influences the price elasticity of demand (Jessoe and Rapson 2014). Because the optimal price regime will depend on how consumers respond to prices, more empirical research could be useful. Finally, empirical research directed at understanding how alternative pricing schemes affect investment in energy efficiency would be valuable.

\subsection{Are beliefs about current and future fuel prices and/or usage systematically uninformed or biased downward?}

Imperfect optimization on the part of consumers is another possible contributor to the energyefficiency gap, but biased beliefs about fuel prices do not seem to be a major factor.

Consumer beliefs about fuel prices. Downwardly biased beliefs about fuel prices would tend to lead to underinvestment in energy-efficient technology. Qualitative interviews suggest people may know current gasoline prices, but lack other essential inputs to valuing vehicle fuel economy (Turrentine and Kurani 2007, 1220-1221). Quantitative survey evidence suggests that, on average, consumers forecast future gasoline prices using current prices (Allcott 2011b, 102-103; S. T. Anderson, Kellogg, and Sallee 2013). ${ }^{21}$

Is the current price an unbiased predictor of future prices? It is crucial to compare ex ante consumer beliefs with other possible ex ante beliefs, rather than using outcomes to judge the beliefs of consumers ex post, because beliefs can turn out to be mistaken after the fact even when they are 
unbiased in expectation. Empirical evidence finds this no-change forecast is a better predictor of future prices than predictions derived from econometric models, professional survey forecasts, and oil futures (Alquist and Kilian 2010, 540). Together, these two findings-consumers forecast using current prices and current prices are more accurate than other conventional forecasting techniques-do not support the argument that downwardly biased beliefs about fuel prices contribute to the energy-efficiency gap. ${ }^{22}$

Consumer beliefs about fuel usage. There is little evidence on gasoline usage forecasts or the contribution of inaccurate usage forecasts to the energy-efficiency gap. Evidence from other settings may be instructive: consumer decisions about mobile phone and health club contracts suggest biased beliefs about product usage (DellaVigna and Malmendier 2006; Grubb 2009). In the context of automobile purchases, consumers may be less likely to misestimate future fuel usage, due to the salience of gasoline expenditures and relative stability in driving patterns for a given individual.

Future research to understand the impact of fuel-price beliefs on investments in energy-efficient technology outside the transportation sector could be valuable. Likewise, studies of the beliefs of firms, or of key decision-makers within firms, could further understanding of the energyefficiency gap. Little research has been done on consumers' predictions of future usage. Without eliciting or recovering these beliefs, assessing the optimality of consumer purchases requires strong assumptions. A research design that combines elicited price and usage forecasts with choice data could possibly recover preferences without bias from heterogeneity in beliefs among consumers.

\subsection{Are beliefs about current and future electricity prices and/or usage systematically uninformed or biased downward?}

Consumer beliefs about electricity prices. Limited evidence suggests consumers may be misinformed about current electricity prices, but there is no evidence of a systematic bias. Consumers respond to average, rather than marginal, price (Ito 2014, 548-554), but appear to reduce consumption in response to a reduction in price, in contrast to theoretical predictions (Jessoe, Rapson, and Smith 2014). This could be a product of consumer inattentiveness, but research is needed to distinguish this from competing explanations (Faruqui and Sergici 2011; Ito, Ida, and Tanaka 2014). In contrast, other research has provided evidence that consumers value changes in physical energy use (for example, $\mathrm{kWh}$ of electricity and therms of natural gas) at close to their price (Newell and Siikamäki 2014). 
Consumer beliefs about electricity usage. Experimental choice data suggest consumers are also misinformed about electricity usage or about how daily activities translate into usage; consumers provided with real-time usage feedback become significantly more price responsive than consumers without such feedback (Jessoe and Rapson 2014). ${ }^{23}$ In consumer surveys, respondents systematically overestimate the energy costs of low-usage goods (for example, computers) and underestimate the energy costs of high-usage goods (for example, water heaters) (Attari et al. 2010).

Separately identifying beliefs and preferences is obviously challenging. Economic research in this area typically makes assumptions_-sometimes quite strong assumptions_about beliefs in order to recover preferences. Future research could begin by eliciting beliefs from economic agents, and then using these beliefs to recover preferences (Manski 2004, 1330). In some contexts, this approach could enable the researcher to isolate multiple effects of information policies (for example, isolate the effect of salience from the effect of information that alters beliefs).

\subsection{Do analysts systematically overestimate energy savings from efficiency investments?}

Analysts' predictions of energy savings from efficiency investments have tended to overstate the magnitude of the energy-efficiency gap. We distinguish between ex ante engineering-economic analyses, ${ }^{24}$ which rely primarily on physical models to predict energy savings, and ex post impact evaluations, which typically rely on observed energy consumption to estimate net savings associated with energy-efficiency investments. Hybrid models combine the technological detail of engineering models with economic evaluations (Murphy and Jaccard 2011).

Expost economic evaluations, using actual energy usage, are generally thought to be more credible than ex ante engineering-economic analyses, ${ }^{25}$ and early comparisons provided evidence of a

In this experiment, the treatment and control groups received the same day-ahead notifications of price changes. This research design isolates the effect of usage feedback and eliminates the potentially confounding effect of salience.

These are also called "bottom-up" or "technology-based" approaches. They typically utilize detailed information about the relative efficiency of various types of energy-using equipment, existing deployment, and assumptions about usage patterns, in order to estimate how energy usage, expenditures, and pollution would change in response to changes in the mix of capital goods. By making assumptions about opportunities for substitution, switching costs, and infra-marginal behavioral responses, these studies have been used to predict the effects of policies. For an early critique of these studies, see Joskow and Marron (1993). In a particularly influential engineering-economic study, McKinsey \& Company estimated a supply curve of carbon-emission reductions in the United States (Granade et al. 2009), and concluded that a substantial amount of reductions could be achieved at negative cost by investing in greater energy efficiency. This result generated considerable interest, and also substantial criticism, partly on the grounds that some costs of adoption were not treated in the analysis.

25 However, ex ante studies offer something ex post approaches do not, namely predictions, which are critical for evaluating alternative energy-efficiency investments on cost-effectiveness grounds, as well as for projecting energy savings associated with any given policy. 
seemingly systematic bias in ex ante predictions (Nadel and Keating 1991). Several explanations for the divergence between engineering models and impact evaluations have been offered: erroneous assumptions about usage; complex interactions omitted from engineering estimates (for example, the rebound effect); quality control problems (for example, problems with equipment installation); and adoption of energy savings measures by non-participants (which lowers net savings attributable to utility programs).

A meta-analysis of 42 utility conservation programs in the residential, commercial, and industrial sectors found that actual energy-savings estimates for residential retrofit programs ranged from 15 to 117 percent of ex ante engineering-economic estimates (Nadel and Keating 1991, 2). Commercial retrofit programs exhibited energy savings ranging from 36 to 248 percent of engineering predictions, while a majority of programs failed to meet savings benchmarks from ex ante analysis (Nadel and Keating 1991, 6). These direct comparisons suggest that caution is warranted when interpreting ex ante engineering-economic evidence for the energy-efficiency gap. Nonetheless, they also found some cases in which ex ante analyses have underestimated energy savings.

Home energy auditors use engineering-based tools to predict energy savings. These tools are one potential source of systematically biased energy-savings estimates for reasons that include user error (for example, incorrect inputs or inaccurate assumptions about post-audit thermostat settings) and improper accounting for residents' behavioral responses, even when the underlying engineering models are correct.

In empirical research, two groups of participants in a utility-weatherization program in the $1980 \mathrm{~s}$ achieved 47 and 78 percent of predicted savings on average (Hirst 1986, 300), ${ }^{26}$ while realized savings from another utility program ranged from 50 to 81 percent of predicted electricity savings, and 14 to 42 percent of predicted natural gas savings (Sebold and Fox 1985, 83). In another study, a tool used for weatherization home audits over-predicted savings by 186 percent, despite accurate engineering calculations (Ternes and Gettings 2008). Likewise, weatherization projects in New York State only achieved 57 to 69 percent of the savings predicted by the National Energy Audit Tool, and studies from other states reach qualitatively similar conclusions (L. G. Berry and Gettings 1998).

Analyses that significantly overestimate energy savings persist, despite substantial improvements in ex ante engineering-economic methods over time. For example, ex post analysis of the "Cash for Coolers" program in Mexico, which provided subsidies for the replacement of inefficient 
household appliances, indicates refrigerator replacement achieved only one-quarter of annual savings predicted by the World Bank. Replacement of air-conditioners led to increased electricity consumption, in stark contrast to engineering predictions of energy savings (Davis, Fuchs, and Gertler 2014). In a randomized utility experiment providing insulation and HVAC appliances to certain households, ex ante engineering estimates overstated actual conservation by 13 percent (Dubin, Miedema, and Chandran 1986).

Scrutiny of the rates of return predicted by ex ante engineering-economic analyses also provides evidence of bias in energy-savings estimates. Econometric analysis of home energy-efficiency investments by Metcalf and Hassett $(1999,527)$ suggests the median rate of return for insulation improvements is 9.7 percent, consistent with reasonable discount rates, but far below the ex ante estimates of Blasnik (1990). A combined engineering/econometric approach to estimating these rates of return finds broadly similar results: Dubin and Henson (1988) estimate average rates of return of 4.9 percent for ceiling insulation and 8.3 percent for wall insulation. ${ }^{27}$

There are significant opportunities for continued research in this area. First, more attention is needed to ex post analysis in the transportation, commercial, and industrial sectors. The preponderance of evidence brought to bear on this question of accuracy in ex ante energysavings predictions has come from the residential sector, probably because of the large number of government and utility programs that provide existing engineering analysis and rich data for ex post assessment. More ex post analyses of model predictions are needed to better judge whether ex ante engineering-economic analyses continue to systematically overstate the savings associated with energy-efficiency investments or whether these approaches have improved. ${ }^{28}$ There may have been a selection bias whereby researchers have chosen to evaluate engineering-economic analyses that have most exaggerated the savings potential of efficiency investments.

\subsection{Do analysts insufficiently account for consumer heterogeneity?}

For any energy-efficiency technology, the benefits and costs of adoption can vary substantially across potential adopters (Fowlie, Greenstone, and Wolfram 2014; Metcalf and Hassett 1999, 526; Alberini, Bareit, and Filippini 2014, 33-4; Newell and Siikamäki 2014). Even when engineering

Simulation-based studies, which use energy-market models to trace out energy-efficiency supply curves, improve on simpler ex ante analyses. These models explicitly model complex adoption decisions, consumer heterogeneity, uncertainty, and feedback effects. As a result, even if these models begin with the same technology assumptions as simpler engineering-economic models, the general equilibrium effects of these interrelationships lead to different, typically lower, predicted levels of end-use energy efficiency. One study found that incorporating these factors reduces the size of the energy-efficiency gap identified in the McKinsey \& Company study (Granade et al. 2009) by three-quarters (Huntington 2011, 19).

Some such assessments have improved by accounting for "free riders" that would have adopted technologies even in the absence of certain programs, and by incorporating the rebound effect (Dubin and Henson 1988, 133; Davis, Fuchs, and Gertler 2014; Gillingham and Palmer 2014, 21; Sorrell, Dimitropoulos, and Sommerville 2009; Greening, Greene, and Difiglio 2000). 
predictions correctly find that, on average, the benefits of adoption exceed the costs of adoption, this will not be true for some potential adopters.

Differences in benefits and costs across agents generate variation in observed rates of adoption (Griliches 1957). Similarly, heterogeneity across consumers may explain variation in the adoption of energy-efficient technology. For example, (Hausman and Joskow 1982) pointed out that heterogeneity in usage profiles, capital stock, or consumer preferences could result in realized savings below average predicted savings. Failure to model heterogeneity correctly can introduce bias in estimates of the size of the energy-efficiency gap. ${ }^{29}$

If the bias due to heterogeneity is systematic, analyses ignoring heterogeneity could overstate the magnitude of the energy-efficiency gap. The sign of this bias is ambiguous, but can be identified. Neglecting consumer heterogeneity appears to have produced empirical estimates that over-state the extent to which vehicle purchasers undervalue fuel economy (Bento, Li, and Roth 2012, 45). Ignoring heterogeneity can bias energy-savings estimates upward: systematic differences between past and future adopters can drive a wedge between observed and potential returns for a given investment. This wedge is likely positive in a context where consumers and firms have selected the most profitable projects first, as prospective returns will likely be below historical average returns.

One potential area for future research involves using randomized experiments to better understand the distribution of energy savings associated with a given investment by comparing the distribution of energy outcomes for treated and control groups. This could help improve ex ante predictions for future decision-making. Wider use of techniques from industrial organization (for example, the random coefficient logit model) could improve predictions by explicitly modeling heterogeneity.

\section{ARE PRODUCT CHOICES COST-MINIMIZING IN PRESENT- VALUE TERMS?}

The framework posited in part 1 of this paper is one of cost-minimizing energy-efficiency decisions, and so it is natural to ask whether product choices are cost-minimizing in present value terms, or whether various market failures and/or behavioral phenomena inhibit such cost-minimization.

Here the empirical evidence ranges from strong (split incentives/agency issues and inattention/ salience phenomena) to moderate (heuristic decision-making/bounded rationality, systematic risk, and option value) to weak (learning-by-using, loss aversion, myopia, and capital market failures). It is important to recognize, however, that here as elsewhere in our review of existing research, we find that most previous work has focused on the residential sector, with much less attention given to the commercial and industrial sectors-presumably at least partly because of 
data being unavailable. The availability of data for further research varies by topic, with split incentives/agency issues and effects of myopia offering the most promising opportunities for further investigation.

That said, given the wide application of building codes and energy-efficiency standards, split incentives/agency problems in the residential, commercial, and industrial sectors may not be as severe as one might expect in the absence of any interventions. Overall, some areas merit priority for future research, such as empirical analysis of split incentives/agency issues in markets for technologies that are not subject to efficiency standards (such as electric motors). And much more work can be done in the behavioral realm (on issues such as inattention/salience, loss-aversion/ reference points, heuristic decision-making, and myopia), as well as on capital market failures and systematic risk.

\subsection{Do split incentives/agency issues due to asymmetric information inhibit energy-efficient decisions?}

Differences in interests between economic agents frequently arise linked with problems of agency or split incentives. Prominent examples include landlord-tenant and builder-buyer problems, in which capital investors may make decisions that are not optimal from the perspective of the end user. Similarly, agency conflicts are possible within firms when investment and operating decisions are divided among individuals or business units (Tietenberg 2009, 308). Research has long cited these conflicts as potential explanations for the energy-efficiency gap (Blumstein et al. 1980; Fisher and Rothkopf 1989; DeCanio 1993; Jaffe and Stavins 1994a; Jaffe and Stavins 1994b; Gillingham, Newell, and Palmer 2009; Tietenberg 2009; Gillingham and Palmer 2014).

Empirical evidence has confirmed the existence of the principal-agent problem, and comprehensive accounting exercises have sought to estimate the potential importance of this market failure by quantifying the amount of energy consumption subject to incentive conflicts (IEA 2007). For example, 35 percent of U.S. residential energy use may be affected (Murtishaw and Sathaye 2006, 31-2). Other research has compared owner-occupied and rental properties to estimate directly the impacts of split incentives. Most results are compelling: even after controlling for household income and other household characteristics, renters are significantly less likely to have energy-efficient refrigerators, clothes washers, and dishwashers based on data from the Residential Energy Consumption Survey (Davis 2012). Owner-occupied dwellings in California are 13 and 20 percent more likely to have exterior wall and ceiling insulation (Gillingham, Harding, and Rapson 2012). In contrast, a hedonic regression analysis of survey data in Australia failed to find evidence of split incentives in rental housing (Wood, Ong, and McMurray 2012).

Other evidence supports the hypothesis that information asymmetries exist in housing markets. Data from the United States show that landlords include utilities in rental prices even when 
units are individually metered. This may be because landlords with energy-efficient units cannot credibly communicate this information and instead include utilities as a signal of the units' efficiency (Levinson and Niemann 2004, 51-57). Landlords may even use utility-included rental contracts to attract renters or as a signal of other unobservable forms of quality unrelated to energy efficiency. The empirical correlation between how well-maintained a unit is and the inclusion of utilities in rent provides some support for this hypothesis (S. J. Choi and Kim 2012, 35-36).

More support for the hypothesis of asymmetric information comes from stated preferences. Responding to a survey, New Zealand tenants stated that they would be willing to pay higher rents in exchange for improved energy efficiency and, in many cases, respondents' willingness to pay appears to justify landlord investments in energy-efficiency improvements. Asymmetric information could explain why landlords do not make such seemingly profitable efficiency investments (Phillips 2012, 118-121). In contrast, recent research on commercial buildings finds little evidence of asymmetric information between building owners and prospective buyers or tenants (Papineau 2014, 23-24).

Although such studies provide evidence regarding the hypothesis of asymmetric information, they do not provide direct estimates of the impact of information asymmetries on investments in energy efficiency. While a market failure exists, the magnitude may be small because the energy impacts of inefficient appliances and less insulation only amount to a few percent of total energy consumption in rental units (Davis 2012; Gillingham, Harding, and Rapson 2012).

Alternative contract structures can contribute to another, less cited outcome: moral hazard. For example, tenants who sign energy-inclusive rental agreements face zero marginal cost from energy consumption and therefore may use too much energy relative to the social optimum. Indeed, tenants appear to keep indoor temperatures higher during winter months and when their homes are unoccupied, when utilities are included in their leases (Maruejols and Young 2011, 3667; Levinson and Niemann 2004, 53). Similarly, tenants who pay for utilities are more likely to adjust heating temperatures at night than tenants who face zero marginal cost (Gillingham, Harding, and Rapson 2012). Such findings do not relate directly to investment in energy efficiency, except to the degree that landlords respond strategically to such behavior. However, even if landlords do respond strategically, they are more likely to invest in high-efficiency appliances or decouple rental agreements and energy use than they are to underinvest in energy efficiency. Thus moral hazard is unlikely to contribute to the energy-efficiency gap.

The best evidence available is concentrated in the residential sector, but agency problems due to information asymmetries could also play a role in commercial and industrial sector energyefficiency decisions. Research confirms that firms are also susceptible to internal principal-agent problems. Green Lights, a program that provides technical assistance to (voluntarily) participating firms, enabled cost-saving lighting upgrades that these firms had not installed independently. 
Program experience suggests that firms failed to install these cost-effective measures before the program due to internal cases of principal-agent conflict: capital rationing by managers and split incentives across divisions (Howarth, Haddad, and Paton 2000). Likewise, case studies of the electric motor market in Europe identified split incentives as a barrier to investments in energy efficiency (de Almeida 1998; Ostertag 2003).

Despite the frequency with which the principal-agent problem is named as a contributor to the energy-efficiency gap, there are few formal agency models adapted to this setting. Experimental work is difficult in many settings, since researchers cannot randomly assign landlords and tenants to properties. Therefore, creative empirical strategies (Myers 2013) and new data sources may be needed.

The structure of the principal-agent problem may create opportunities for creative policy responses, as well. Eliminating information asymmetries or innovation in the form of contracts could allow private markets to overcome misaligned incentives. For example, Japan requires the vending machine operator-rather than the owner of the property where the machine is installed - to pay for the machine's energy use (IEA 2007, 164). Nonetheless, vending machines are also subject to minimum efficiency standards in Japan.

\subsection{Do learning-by-using spillovers inhibit more energy-efficient decisions?}

In many cases, consumers learn about the benefits of a given technology by adopting and experiencing it. In some cases, other consumers benefit from this information without having adopted the technology. A positive informational spillover could slow the rate of technology adoption relative to the social optimum, as each consumer has an incentive to delay adoption in order to learn from others. Put another way, the opportunity for individuals to substitute their peers' experiences for their own creates an incentive to free-ride (Foster and Rosenzweig 2010, 408). At least in theory, this phenomenon could contribute to the energy-efficiency gap. ${ }^{30}$

Empirical research in other domains emphasizes the prevalence of social learning and peer effects (Case and Katz 1991; Ammermueller and Pischke 2009; Duflo and Saez 2002; Foster and Rosenzweig 1995, 1205-6; Emerick 2014; Conley and Udry 2010, 37-38), but there is limited evidence regarding how information spillovers affect energy-efficient technology, and-if positive spillovers exist-whether consumers respond by free-riding. The bulk of the evidence on information spillovers comes from the introduction of hybrid vehicles, drawing on both stated preference (Mau et al. 2008) and revealed preference studies (Axsen, Mountain, and Jaccard 
2009, 237; Narayanan and Nair 2013, 72-72). ${ }^{31}$ In the residential sector, a study of thermal insulation choices by homebuilders found no evidence of large knowledge externalities among builders, suggesting builders do not learn from the adoption of these technologies by competitors (Jaffe and Stavins 1995, S-60). ${ }^{32}$

Theoretical research from other fields highlights the potential importance of social learning and peer effects (Manski 1993a), and underscores the potential for social learning to lead to inefficient technology adoption decisions, even irrespective of free-ridership. Information spillovers in the context of irreversible technology choice with network externalities can result in proven technologies being chosen over other alternatives with higher expected value (J. P. Choi 1997). Similarly, a model in which it is rational to adopt technology based on the adoption decisions of others (for example, because the decisions of others may reflect information that agents lack) predicts herd behavior in which agents make decisions that depart from the decision they would make using only private information. This can lead to inefficient outcomes, as agents collectively undermine the benefits of learning by taking cues from others rather than relying on private information (Banerjee 1992, 798).

Previous research illustrates the challenge of credibly identifying spillovers using observational data (Narayanan and Nair 2013; Manski 1993b). The challenge is to disentangle spillover effects from unobservables (Foster and Rosenzweig 2010, 411). Even then, empirically testing for the presence of learning spillovers does not determine that these spillovers contribute to the energyefficiency gap, through individuals free-riding and thus slowing the overall rate of technology adoption. Further research would be needed to determine the effect of learning spillovers on the adoption of energy-efficient technology, potentially through the use of experimental techniques (Baird et al. 2014).

\subsection{Does inattention to, and/or a lack salience of, energy use/operating costs inhibit energy-efficient decisions?}

Broadly speaking, there is considerable evidence that consumer inattention to non-salient costs affects decisions. Evidence from experiments and observational data reveal that consumers are inattentive to sales taxes (Chetty, Looney, and Kroft 2009), shipping charges (Hossain and Morgan 2006), and out-of-pocket costs for health care (Abaluck and Gruber 2011). Conceptually, inattention may contribute to the energy-efficiency gap to the degree that energy costs are not

Learning spillovers from hybrid technology are not always positive. Analysis of both the Toyota Prius and the Honda Insight suggests that while higher market penetration by the Prius leads to increased adoption of all hybrids, higher market penetration by the Insight leads to reduced adoption (Heutel and Muehlegger 2014, 3-4).

32 An alternative explanation acknowledged by Jaffe and Stavins (1995) is that builders have complete (or close to complete) information, so there is no scope for learning from the adoption decisions of others. 
salient for the investment decision. In some markets, this contribution could be substantial. Almost half of surveyed vehicle buyers report making their decisions without considering fuel costs (Allcott 2011b, 100). This is consistent with earlier research that found that consumers largely ignored replacement ink prices when making printer purchase decisions (R. Hall 1997).

There are two fundamental ways to frame research on inattention. One is a reduced-form approach, empirically estimating an attentiveness parameter without taking a stance on the underlying structural model of inattention. This approach can produce credible estimates of the relative importance of inattention in a given context, but it falls short of describing the mechanisms that underlie inattention. The other is to develop a model of the decision process itself, making explicit the underlying factors at play.

Intuition suggests that consumers will only allocate attention to an attribute if the cognitive costs of doing so are less than the expected utility gains. Thus, the level of inattentiveness should vary across individuals and decision environments. Modeling inattention to energy efficiency as a result of costly information acquisition offers one way to explain decisions that are apparently privately sub-optimal (Howarth and Andersson 1993; Sallee 2013).

There are two leading methods for testing for inattention to energy efficiency in empirical research. First, the reduced form of attentiveness suggests comparing demand elasticities with respect to prices and energy costs from market data. This is the empirical approach taken in many studies of discrete choice, which assess the tradeoff consumers make between purchase price and future energy operating costs (Hausman 1979; Dubin and McFadden 1984; Jaffe and Stavins 1995; Goldberg 1998; S. T. Anderson and Newell 2004; Sallee, West, and Fan 2009; Busse, Knittel, and Zettelmeyer 2013; Allcott and Wozny 2014). ${ }^{33}$ The primary shortcoming of this method is that price and energy-cost elasticities can diverge for multiple reasons, including discounting behavior.

Experimental manipulations of salience provide an alternative means of studying inattention to energy efficiency. Field experiments designed to study light bulb choice provide mixed evidence on the impact of an intervention that targets both salience and information: an online intervention increased average willingness to pay for compact fluorescent light bulbs (CFLs) by over two dollars, while an in-store intervention had no statistically significant effect on CFL demand (Allcott and Taubinsky 2013, 3-4). Stated choice experiments that vary the type of information available to consumers, be it economic, physical energy, or environmental, can also help assess which of these is most salient to consumers (Newell and Siikamäki 2014). Experimental studies are limited by concerns about distinguishing inattention from incomplete information, demand effects, and external validity. Complementary use of experimental and non-experimental techniques can ameliorate the shortcomings of each approach (Chetty, Looney, and Kroft 2009). 
Economic theory and empirical research provide some guidance for policies to address inattention to energy efficiency. Targeting inattentive consumers could enhance policy cost-effectiveness. Information disclosure could target consumers with biased beliefs and those inattentive to future energy costs. The success of information disclosure policies depends crucially on salience as well as on other context-specific factors. In contrast to information disclosure, subsidies may be poorly targeted for combating inattention if the consumers who know about them also tend to be attentive to future energy costs. ${ }^{34}$ That said, there is an alternative argument for poorly targeted taxes and subsidies if these interventions do raise salience or otherwise reduce inattention; such interventions generate first-order welfare gains for inattentive consumers and only second-order distortions for attentive consumers (O'Donoghue and Rabin 2006).

Policies can also lower the cost of attention, and even blunt policies could be justified if they lower the cost of attention sufficiently (Sallee 2013,32). Several recent studies investigate firm responses to coarse policy designs and attempt to quantify the welfare impacts of these policies (Sallee and Slemrod 2012; Houde 2014a; Houde 2014b).

Debates over price and information interventions to address inattention highlight a broader question of instrument choice. A number of recent studies contribute evidence on the effect of different policy instruments on welfare and energy-efficiency outcomes. Pigouvian taxes on fuels are the natural response to the externalities associated with energy use. Yet there may also be a case for product-market-price interventions if consumers are inattentive to energy costs (Allcott, Mullainathan, and Taubinsky 2014). Minimum efficiency standards are another alternative used by regulators; in some cases, such standards can lead to an effective ban on certain classes of products (Allcott and Taubinsky 2013). In addition to regulatory mandates for disclosure and product certification, information interventions by utilities, and in particular peer comparisons, have been successful in reducing residential energy use and may be applicable elsewhere (Allcott 2011a; Ayres, Raseman, and Shih 2013; Allcott and Rogers 2014).

Experimental techniques, including belief elicitation, may offer some of the most promising opportunities for future research. Beliefs cannot be observed, but researchers could elicit stated beliefs along with stated preferences in field experiments that present consumers with actual choices. In this way, researchers could validate stated preferences using revealed preferences. Researchers can also directly test models of inattention, which offer testable predictions that are unlikely to be confounded by alternative explanations (Sallee 2013).

The literature on retirement savings also speaks to this problem of targeting: for example, Chetty et al. (2014) conclude that automatic retirement account contributions are more effective than subsidies in promoting retirement savings, because subsidies only affect the savings of attentive workers. 


\subsection{Do loss-aversion or reference points inhibit more energy-efficient decisions?}

Research in psychology has highlighted the importance of loss aversion and reference points in economic decisions. Empirical insights have been formalized in prospect theory and related alternatives to expected utility theory (Kahneman and Tversky 1979; Thaler 1985; Tversky and Kahneman 1991; Köszegi and Rabin 2006). ${ }^{35}$ Yet despite strong evidence in other decision environments and general theoretical frameworks for analysis, very little is known about the impacts of loss aversion and reference points on energy-efficiency investments.

The most relevant evidence comes from experimental research on energy use (Allcott 2011a; Goldstein, Cialdini, and Griskevicius 2008), with responses partially attributable to changes in reference points. Survey evidence on consumer demand for vehicle fuel economy is also consistent with loss aversion (Greene, Evans, and Hiestand 2013).

Governments and businesses can influence reference points through careful choice of defaults and goals. In three experiments, replacing incandescent light bulbs with CFLs as the default significantly increased the proportion of subjects who chose CFLs (Dinner et al. 2011). Goals can also serve as reference points under prospect theory (Heath, Larrick, and Wu 1999, 8394). If the importance of goal-based reference points holds in practice, encouraging consumers to adjust personal goals could encourage investments in energy efficiency. In one experiment, providing tailored information, goals, and personalized feedback led households to reduce energy use on average, although the effect was not statistically distinguishable from the control group (Abrahamse et al. 2007).

Consumers and firms considering energy efficiency improvements are almost certainly susceptible to reference points and loss aversion, but empirical research is needed to quantify the importance of these phenomena. Future work could synthesize previous experimental techniques to study how different types of information displayed on energy labels influence reference points. Challenges to implementing policy based on existing research include heterogeneity — that no one level of energy efficiency is right for every consumer-and concerns over paternalism, which is a valid concern if reference points can be manipulated. Research on policy interventions (such as energy labels) could inform the design of uniform interventions that minimize the welfare cost of providing blunt guidance. Carefully targeted interventions could shift reference points for some consumers without creating incentives for other consumers to alter their behavior.

See also Tversky and Kahneman (1981) and (1992). More recent theoretical and experimental work in psychology also highlights the importance of reference dependence. Query theory hypothesizes that consumers consider discrete arguments for or against a given alternative, and that the number of considerations and the order in which they come to mind affects decision-making (Weber and Johnson 2009, 63; Weber et al. 2007). This theory underscores the importance of defaults. As another example, Hardisty, Appelt, and Weber (2013) study the combination of loss aversion and intertemporal decision-making. This research highlights the need to strive for a comprehensive understanding of decision-making to explain the energy-efficiency gap. 


\subsection{Does heuristic decision-making and/or bounded rationality inhibit more energy-efficient decisions?}

Cognitive limitations could conceivably contribute to the energy-efficiency gap by preventing individuals (or possibly firms) from properly balancing present value benefits and costs when investing in energy-using capital goods (Gillingham, Newell, and Palmer 2009, 608-610). This could manifest itself in the use of heuristics or simple optimization errors. Many empirical studies are consistent with these explanations (Sanstad and Howarth 1994, 1.178). However, it is difficult to disentangle the role of heuristics and bounded rationality from competing explanations, because consumers' decision processes cannot be directly observed and because there is no unified theory of decision-making subject to cognitive limitations from which to draw testable hypotheses (Conlisk 1996).

That said, studies of vehicle fuel economy provide some support for the hypothesis of bounded rationality. First, experimental evidence has revealed that consumers systematically misperceive the information contained in fuel economy ratings, due to the inverse relationship between gasoline consumption and miles per gallon ("the MPG illusion") (Larrick and Soll 2008; Allcott 2013). Other research has shown that stated preferences for cars of various efficiencies depend on the metric and scale of information provided on energy labels (Camilleri and Larrick 2014). Translations of fuel economy into multiple perfectly correlated metrics (that is, gallons per mile, estimated annual fuel cost, and greenhouse gas rating) alter stated preferences (Ungemach et al. 2013).

This research may provide guidance for regulatory changes that would encourage energy efficiency. The findings suggest that tailoring the scale of energy labels based on the expected lifetime of a given product or providing multiple translations of energy-efficiency metrics could help guide decisions (Camilleri and Larrick 2014; Ungemach et al. 2013). To some extent, this is already happening: the U.S. Environmental Protection Agency recently redesigned new vehicle labels to include gallons per miles, multiple cost estimates, comparisons with other vehicles in the same class, and environmental ratings (U.S. Environmental Protection Agency 2015).

There are numerous opportunities to study the effects of cognitive limitations on energy-efficiency decisions. Most direct evidence is from laboratory studies of stated preferences. More research on revealed preferences in real decision environments could complement these studies, but-as noted above-the key research-design challenge, particularly in revealed preference studies, is credibly distinguishing the effects of heuristic decision-making and bounded rationality from other explanations of behavior. 


\subsection{Does myopia/short-sightedness inhibit more energy-efficient decisions?}

A key issue surrounding the question of whether myopia contributes to the energy-efficiency gap involves identifying the discount rates used by consumers and analyzing whether these discount rates are consistent with maximizing present-value net benefits. There is a long history of observing consumers' choices of energy-consuming durable goods to examine the tradeoff between upfront capital costs and operating costs. If consumers are seeking to minimize discounted lifecycle costs, it becomes possible to estimate implicit discount rates. ${ }^{36}$

The seminal study of this kind was by Hausman (1979, 50). This study found average implicit discount rates in excess of 20 percent. Many other researchers subsequently found implicit discount rates much higher than market interest rates (Dubin and McFadden 1984, 354; Gately 1980). ${ }^{37}$ Such findings have been interpreted as evidence of myopia, the existence of other behavioral issues or market failures, or alternatively as evidence of rational discounting subject to liquidity constraints. Studies that identify a discount rate while assuming cost-minimizing behavior cannot, however, distinguish myopia as an underlying cause of the energy paradox from other possible causes (Newell and Siikamäki 2014). For example, high implicit discount rates for home energy investments could also be rationalized by moral hazard: contractors may provide low quality services, and consumers may use high hurdle rates to insulate themselves from this risk (Giraudet and Houde 2014). ${ }^{38}$

Automobile purchases provide a good setting to study these questions because such purchases are major decisions, about which consumers presumably think carefully, and because the cost of gasoline has varied substantially over time (Helfand and Wolverton 2011). One study has found that consumers are indifferent between $\$ 0.76$ now and $\$ 1.00$ of discounted future gasoline expenditures, suggesting the possibility of myopia or undervaluation of fuel economy (Allcott and Wozny 2014). On the other hand, other studies have found that market outcomes are consistent with dynamically cost-minimizing behavior (Busse, Knittel, and Zettelmeyer 2013; Sallee, West, and Fan 2009). Evidence from gasoline and diesel car purchases in Europe in the early 1990s suggests an implicit discount rate of about 11.5 percent, only slightly above automobile loan rates at the time (Verboven 2002, 288). However, research has not always taken into account the fact

36

Of course, it is also possible that consumers are not minimizing aggregate costs because of errors regarding time horizons, their beliefs, or due to inattention, in which case these studies will not reveal true consumer discount rates (Allcott and Wozny 2014, 4).

37

38

Train (1985) and Sanstad, Hanemann, and Auffhammer (2006) review other examples.

An alternative way to frame the consideration of myopia is with experimental research and alternative theories at the intersection of psychology and economics. Research on intertemporal decision-making from other contexts provides robust evidence that individuals are dynamically inconsistent (Loewenstein and Thaler 1989, 183-6), and delay costly up-front action even when they acknowledge that it is in their long-run interest (Akerlof 1991, 3-8). Quasi-hyperbolic discounting provides a theoretical alternative to exponential discounting to explain these empirical anomalies (Laibson 1997).

DUKE UNIVERSITY ENERGY INITIATIVE • HARVARD ENVIRONMENTAL ECONOMICS PROGRAM " 29 
that automobile markets have been subject to fuel economy regulation for many years, which tends to reduce the possibility for high implicit discount rates.

To assess the implications of these studies for the energy-efficiency gap, it is necessary to identify a benchmark discount rate, which depends-among other things_-on the cost of capital. One structured choice experiment found that (conditional on information labeling) elicited discount rates rationalized participant decision-making on average, but the use of a common discount rate of five percent for all subjects tended to lead to a conclusion that consumers significantly undervalued energy efficiency (Newell and Siikamäki 2014).

Direct research on intertemporal tradeoffs in energy-efficiency-investment decisions might clarify the contribution of myopia to the energy-efficiency gap. For example, researchers could manipulate intertemporal tradeoffs through information provision and pricing interventions, and examine decision-making. Another promising approach may be to combine elicitation of time preferences with choice data, and compare choices observed across multiple domains (Newell and Siikamäki 2014).

Strategic responses by firms to consumer myopia present another area for potential research. If firms believe consumers are myopic and therefore undervalue energy efficiency, product offerings will not be optimal from a social perspective, even if firms hold incorrect beliefs about consumers. Studies of the automotive industry posit several explanations for the apparently suboptimal level of fuel economy manufacturers provide (Helfand and Wolverton 2011, 137-140). Government policies and regulations also depend on assumptions about consumer myopia and on the discount rate used in regulatory impact analysis.

\subsection{Do capital market failures/liquidity constraints influence consumer discount rates for energy efficiency investments?}

Capital market failures could explain a divergence between estimated implicit discount rates and typical market interest rates. Prospective investors facing capital constraints may be unable to finance energy-efficiency investments, even if future returns would justify the up-front cost. This could result in an estimated implicit discount rate that is above normal market rates. Information asymmetries could prevent efficient lending even for collateralized investments; firms that possess private information about future cost savings from a particular investment may be unable to convince lenders of its financial potential if the savings are costly for the lender to evaluate.

In the future, theoretical and empirical findings from consumer finance research may shed light on specific capital market failures that are most important for energy efficiency. The actual distribution of market interest rates faced by consumers and firms through various lending mechanisms is critical to identifying the appropriate benchmark market interest rate (or range 
of rates). However, it may be difficult to empirically distinguish capital market failures leading to high discount rates from a lack of underlying demand for energy-saving technology (Palmer, Walls, and Gerarden 2012, 29-30).

\subsection{Does systematic risk affect the appropriate discount rate for energy- efficiency analysis?}

The capital asset pricing model (CAPM) presents one way to frame debate about the "correct" discount rate to use for energy-efficiency analysis (Fama and French 2004). The CAPM provides a static optimization framework for determining the appropriate hurdle rate for an investment, based on the risk-free rate of interest, expected returns from a diversified portfolio of assets, and the normalized covariance between the investment's returns and that of the diversified portfolio $(\beta)$. Optimal investment depends on the opportunity cost of capital, not simply the nominal cost of capital.

Under the CAPM, a positive (negative) correlation between energy prices and the rest of the economy would suggest hurdle rates for energy-efficiency investments that are higher (lower) than the returns on a diversified portfolio. A negative relationship between energy prices and the greater economy $(\beta<0)$ supports the use of low hurdle rates, because energy-efficient investments can serve as a hedge. One study found such a negative correlation between the consumer price index for fuels and the S\&P 500 index (Metcalf 1994, 820-1). Likewise, more recent research argues that applying the CAPM to an analysis of vehicle purchases would lower the discount rate due to the low correlation between annual changes in gasoline prices and market returns (Allcott and Wozny 2014, 16-7). For some end uses, the correlation between fuel prices and market returns is artificially low due to regulation. This could also lead to a lower discount rate under the CAPM.

The CAPM may fail as an appropriate benchmark for discount rates for energy-efficiency investment for two primary reasons. First, the model is not ideal for many energy-efficiency investments because of the CAPM's static nature, meaning that the investment choice set, expected investment returns, and covariances among investments are treated as fixed over time. In contrast, energy-efficiency investment opportunities, expected returns, and risk relationships likely vary substantially with technological advance and other exogenous factors. Second, the CAPM assumes that transaction costs are zero, that the investment can be resold on a secondary market, and that investors already hold diversified portfolios when considering a new investment (Sutherland 1991, 28). These assumptions may be tenable in certain contexts (for example, for sizable businesses), but not in others (for example, for low-income households). Third, the model has failed numerous empirical tests (Fama and French 2004, 30-7).

On the other hand, the CAPM's simplicity generates useful intuitions and sharp, testable predictions that enable researchers to assess its utility for energy-efficiency investments. One possible approach would be to use observational data on similar investments utilizing different 
fuels. Prices for various fuels covary heterogeneously with the greater economy. As a result, investment hurdle rates should vary across fuel types. Estimating and comparing these hurdle rates could directly test the CAPM in this realm. However, it may be difficult to eliminate correlated unobservables.

\subsection{Can option value help explain the energy-efficiency gap?}

Option value - the net benefit of delaying an investment even when the investment's net present value is positive-is a general feature of dynamic optimization problems with uncertainty, irreversible investment, and timing flexibility (Dixit and Pindyck 1994). Consumers and firms commonly face decision problems of this type when investing in energy-consuming durable goods with little or no resale value.

This presents an alternative explanation of the energy-efficiency gap: the difference between apparently optimal investment and observed investment may be due to the option value of waiting. Failure to account for this option value could bias estimates of the energy-efficiency gap. In an analysis of irreversible investment in residential energy-efficiency measures under conditions of energy-price uncertainty, Hassett and Metcalf (1993) explained observed technology adoption rates without any reference to market failures. ${ }^{39}$ Potential technological innovation, which would reduce future adoption costs, can also yield option value for delaying energy-efficiency investments (Jaffe and Stavins 1995; Ansar and Sparks 2009, 20).

Energy-price uncertainty is important in some industries. Direct computation, reduced form estimation, and simulation have found large hurdle rates due to energy price volatility based on observed investment decisions (Diederen, van Tongeren, and van der Veen 2003; Löfgren, Millock, and Nauges 2008). ${ }^{40}$ Technological change is the other prominent explanation for investment delay. Evidence from air conditioner purchases indicates that purchase timing depends on expectations about future developments in product efficiency (Rapson 2014). Other relevant sources of uncertainty include future product use, product efficiency, and product life (Greene 2011, 610).

The option value of waiting due to uncertainty regarding future energy prices or technological change may explain part of the apparently sub-optimal investment in energy-efficient technologies,

Sanstad, Blumstein, and Stoft (1995) maintained that the option value analysis of Hassett and Metcalf (1993) suggested an implicit discount rate much lower than actually observed, even when taking irreversibility into account.

In this context, the hurdle rate is the multiplier on the cost of capital that corresponds to the minimum acceptable rate of return for a project to be undertaken. Diederen, van Tongeren, and van der Veen (2003) find hurdle rates of 1.76 for Dutch greenhouses based on simulation, and Löfgren, Millock, and Nauges (2008) econometrically estimate hurdle rates of 3.4 to 3.6 for the Swedish energy and heating sector. 
but probably not a large part in many cases. The option value explanation hinges on four assumptions: irreversibility, uncertainty, flexible timing, and lumpiness of investment (McDonald and Siegel 1986, 725). In practice, one or more of these conditions can fail. Not all energy-efficient investments are irreversible. There are active resale markets for many types of consumer goods and producer capital. Uncertainty may be irrelevant, as in the case of firms that have long-term energy procurement contracts in place, which provide price certainty. In other cases, uncertainty may be relatively unimportant, as in the case of energy-consuming goods with relatively short lifetimes (for example, light bulbs). Finally, the timing of investments in energy-consuming durables is not always flexible (for example, replacement of a broken water heater).

One possible way to assess the relative importance of the option value of waiting due to energyprice uncertainty would be to survey consumers and firms directly. The evidence here is mixed. Energy-price uncertainty ranked fourth out of 15 reported reasons firms did not undertake energy-efficiency investments recommended by auditors in a survey of small- and medium-sized businesses (Fleiter, Schleich, and Ravivanpong 2012, 868). On the other hand, a stated choice experiment in the residential sector revealed a correlation between energy-price uncertainty and a preference for the status quo over energy-efficiency improvements (Alberini, Banfi, and Ramseier 2013). This result is consistent with the basic prediction of the option value model, but does not quantify its relative importance.

\section{DO OTHER UNOBSERVED COSTS INHIBIT ENERGY- EFFICIENT DECISIONS?}

We now turn to the final term in the cost-minimization equation described in section 1 of this paper, and ask whether other costs inhibit more energy-efficient decisions. We find that the empirical evidence in this realm is generally sound, and that needed data for more research are available. We would assign a relatively high priority to research in this area, particularly research aimed at better understanding consumer demand (willingness to pay) for product attributes, which can be useful for the design of better regulatory approaches.

\subsection{Do analysts take sufficient account of product attributes?}

Products of varying efficiencies differ from each other in ways that are often omitted by engineering and econometric analysis, potentially contributing to the misidentification of an energy-efficiency gap. Producers may generate efficiency improvements by trading off other product attributes for enhanced energy efficiency. In that case, consumers will face opportunity costs of decreased product quality, in addition to any price change, when considering energy-efficient products. Ignoring these opportunity costs would bias estimates of consumer choice and welfare, and also bias estimates of the magnitude of the energy-efficiency gap. 
The fundamental problem, in an econometric context, is omitted variable bias. Analyses can be classified in terms of information sets: (1) attributes observed by both the analyst and the consumer; (2) attributes observed by the consumer, but not by the analyst; (3) attributes observed by the analyst, but not the consumer; and (4) attributes observed by neither the analyst nor the consumer. Both engineering and econometric techniques can recover unbiased estimates in all cases except the second.

Early engineering-economic studies compared capital investment and lifetime operating costs to identify cost-effective investments or infer consumer discount rates, disregarding or only partially correcting for non-energy attributes. The prominent McKinsey \& Company study treated compact fluorescent light bulbs as interchangeable with other forms of lighting (Granade et al. 2009, 52), thus ignoring a potentially important source of (unobserved) opportunity costs.

In principle, econometric methods can improve on such engineering methods by including product attributes in analyses of choice data. In practice, however, econometric analysis using cross-sectional data has been limited by the impracticality of observing and accurately measuring all product characteristics. These characteristics are typically subsumed into error terms. The random-coefficients model improved on previous work by modeling unobserved product attributes separately from individual-specific error terms. An early application found significant heterogeneity in demand for automobile fuel economy, suggesting small negative willingness to pay for fuel economy improvements in relatively inefficient vehicles (S. T. Berry, Levinsohn, and Pakes 1995, 878). This reflects heterogeneity in the distribution of consumer preferences, rather than systematic undervaluation of fuel economy.

Subsequent research incorporating micro data in the random coefficients estimation strategy confirmed the importance of heterogeneity, but also found that consumers have a systematic negative willingness to pay for fuel economy (Petrin 2002, 718). These results were driven in part by inadequate control for confounding product attributes that are negatively correlated with fuel economy (for example, weight and horsepower).

Panel data can, in principle, allow researchers to condition on unobserved product attributes that are time-invariant, using differencing or fixed-effects models. Recent studies of this type provide limited evidence for an energy-efficiency paradox: some find market equilibria consistent with correct fuel economy valuation (Busse, Knittel, and Zettelmeyer 2013; Sallee, West, and Fan 2009), while another study finds consumers undervalue fuel savings relative to purchase price (Allcott and Wozny 2014).

One problem with panel data studies of automobile transactions is that these studies assume away short-term responses by producers, such as unobservable changes to purchase terms established during negotiation. Examining other settings could perhaps adjust for this problem; appliance 
attributes, for example, are less susceptible to adjustment by producers in the short run. One study of appliance purchases using transactions data and geographic variation in operating costs (that is, electricity prices) found that consumers undervalue operating costs on average (Houde 2014a, 24-5).

Choice experiments offer another possible way to control for unobserved product characteristics. One approach in a stated-preference context would be to ask subjects to treat all products they consider as identical in non-energy attributes (Newell and Siikamäki 2014). This holds promise for stated preference studies, but is obviously infeasible for revealed preference analysis. Analyses that assess the correlation between energy and non-energy attributes for different products could help identify where the bias from ignoring non-energy attributes is most likely to be present.

\subsection{Do analysts take sufficient account of the costs of implementing energy- efficient options?}

Omitting any (opportunity) cost of adoption from a comparison of the benefits and costs associated with a given energy-efficiency technology will contribute to the impression of an energy-efficiency paradox. Such omitted costs can take many forms, including time spent researching investment alternatives, unobserved implementation costs, and reallocation of resources within a firm. In particular, costs that are less easily quantified are more likely to be omitted by analysts (Granade et al. 2009, 25; Huntington 2011,8). But these costs may serve as real barriers to investmentnot optimization errors or market failures - and should be included in an unbiased analysis of the energy-efficiency gap.

Consumers face a set of adoption costs beyond the most obvious costs of a technology's purchase price and direct installation charges. For example, homeowners have attributed the decision not to install or upgrade attic insulation to the hassle of clearing stored items from the attic space (Caird, Roy, and Herring 2008, 156). A policy experiment in the United Kingdom found that lowering such costs by offering attic cleaning would increase insulation investments (U.K. Department of Energy and Climate Change 2013, 4-5). Another study estimated opportunity costs for adopting thermal insulation to be more than twice the costs of materials and labor (Sharma 2011, 61).

In the commercial and industrial sectors, case studies and survey evidence provide the bulk of the empirical evidence (Fleiter, Schleich, and Ravivanpong 2012, 864-7), with firms indicating that production disruptions and inconvenience can preclude investment in energy efficiency (Rohdin and Thollander 2006; Thollander and Ottosson 2008). Survey respondents also cite lack of time as a barrier, highlighting the role of opportunity cost in simply considering investments (Sorrell et al. 2004; Thollander, Danestig, and Rohdin 2007; Schleich 2009; Trianni and Cagno 2012). Furthermore, recipients of industrial energy audits who failed to undertake recommended investments attributed their decisions to unmeasured costs and risks not considered in the audit analysis (S. T. Anderson and Newell 2004, 30). 
In principle, there is no reason analysts cannot incorporate these additional costs, but in practice data and measurement challenges often inhibit their ability to do so. One route forward may be to treat such costs as unobservables to be recovered through structural estimation techniques. Experimental and quasi-experimental research designs offer another possible avenue for quantifying these costs.

\section{CONCLUSION}

Energy-efficient technologies offer promise for reducing the costs and environmental damages associated with energy use, but these technologies appear not to be used by consumers and businesses to the degree that would be justified, even on the basis of their private financial net benefits. With this in mind, we have examined the "energy paradox," the apparent reality that some energy-efficiency technologies that would pay off for adopters are nevertheless not adopted, as well as the broader phenomenon we characterize as the "energy-efficiency gap," the apparent reality that some energy-efficiency technologies that would be socially efficient are not adopted. The contrast is between private and social optimality, which ultimately has important implications for the role of various policies, as well as their expected net benefits.

We began by decomposing cost-minimizing energy-efficiency decisions into their fundamental elements, which allowed us to identify four major questions, the answers to which are germane to sorting out the causes (and reality or lack thereof) of the paradox and gap. First, we asked whether the energy efficiency and associated pricing of products on the market are economically efficient. To answer this question, we examined the variety of energy-efficient products on the market, their energy-efficiency levels, and their pricing. Although the theory is clear, empirical evidence is - in general - quite limited. More data that could facilitate potential future empirical research are becoming available, although firm-level data are much less plentiful than data on consumers. We do not see this area as meriting high priority for future research, however, with the exception of research that evaluates the effectiveness and efficiency of existing energy-efficiency information policies and examines options for improving these policies.

Second, we asked whether energy operating costs are inefficiently priced and/or understood. Even if consumers make privately optimal decisions, energy-saving technology may diffuse more slowly than the socially optimal rate, because of negative externalities. So, even if the energy paradox is not present, the energy-efficiency gap may be. As in the first realm, the theoretical arguments are strong. Empirical evidence is considerable, and in many cases data are likely to be available for additional research. Existing policies appear not to be sufficient from an economic perspective, suggesting that further research is warranted. Indeed, we ascribe high priority to the pursuit of research in this realm.

Third, we asked whether product choices are cost-minimizing in present-value terms, or whether various market failures and/or behavioral phenomena inhibit such cost-minimization. We found 
that the empirical evidence ranges from strong (split incentives/agency issues and inattention/ salience phenomena) to moderate (heuristic decision-making/bounded rationality, systematic risk, and option value) to weak (learning-by-using, loss aversion, myopia, and capital market failures). Importantly, here, as elsewhere in our review, the bulk of previous work has focused on the residential sector and much less attention has been given to the commercial and industrial sectors. Some areas merit priority for future research, such as empirical analysis of split incentives/ agency issues in areas where efficiency standards are not present, and much more work can be done in the behavioral realm.

Fourth, we asked whether other unobserved costs may inhibit energy-efficient decisions. We found that the empirical evidence is generally sound, and that data needed for more research are available. We assign a relatively high priority to future research, particularly to aid understanding of consumer demand for product attributes that are correlated with energy efficiency, thereby informing policy and product development decisions.

Finally, we can ask what these findings have to say about our three categories of explanations for the apparent underinvestment in energy-efficient technologies relative to the predictions of some engineering and economic models: (1) market failures, (2) behavioral effects, and (3) modeling flaws. Potential market-failure explanations include information problems, energy market failures, capital market failures, and innovation market failures. Potential behavioral explanations include inattentiveness and salience, myopia and short sightedness, bounded rationality and heuristic decision-making, prospect theory and reference-point phenomena, and systematically biased beliefs. Finally, potential modeling flaws include unobserved or understated costs of adoption; ignored product attributes; heterogeneity in benefits and costs of adoption across potential adopters; use of incorrect discount rates; and uncertainty, irreversibility, and option value.

It turns out that all three categories of explanations are theoretically sound and that limited empirical evidence exists for every category as well, although the empirical research is by no means consistently strong across all of the specific explanations, as we highlight above. The validity of each of these explanations - and the degree to which each contributes to the energy-efficiency gap-are relevant for crafting sensible policies, so we hope our review can help inform both future research and policy. Given the many energy-efficiency policies and programs that are already in place, we also place a high priority on research that evaluates the effectiveness, cost-effectiveness, and overall economic efficiency of existing energy-efficiency policies, as well as options for their improvement. 
Figure 1:

\section{Alternative Notions of the Energy-Efficiency Gap}

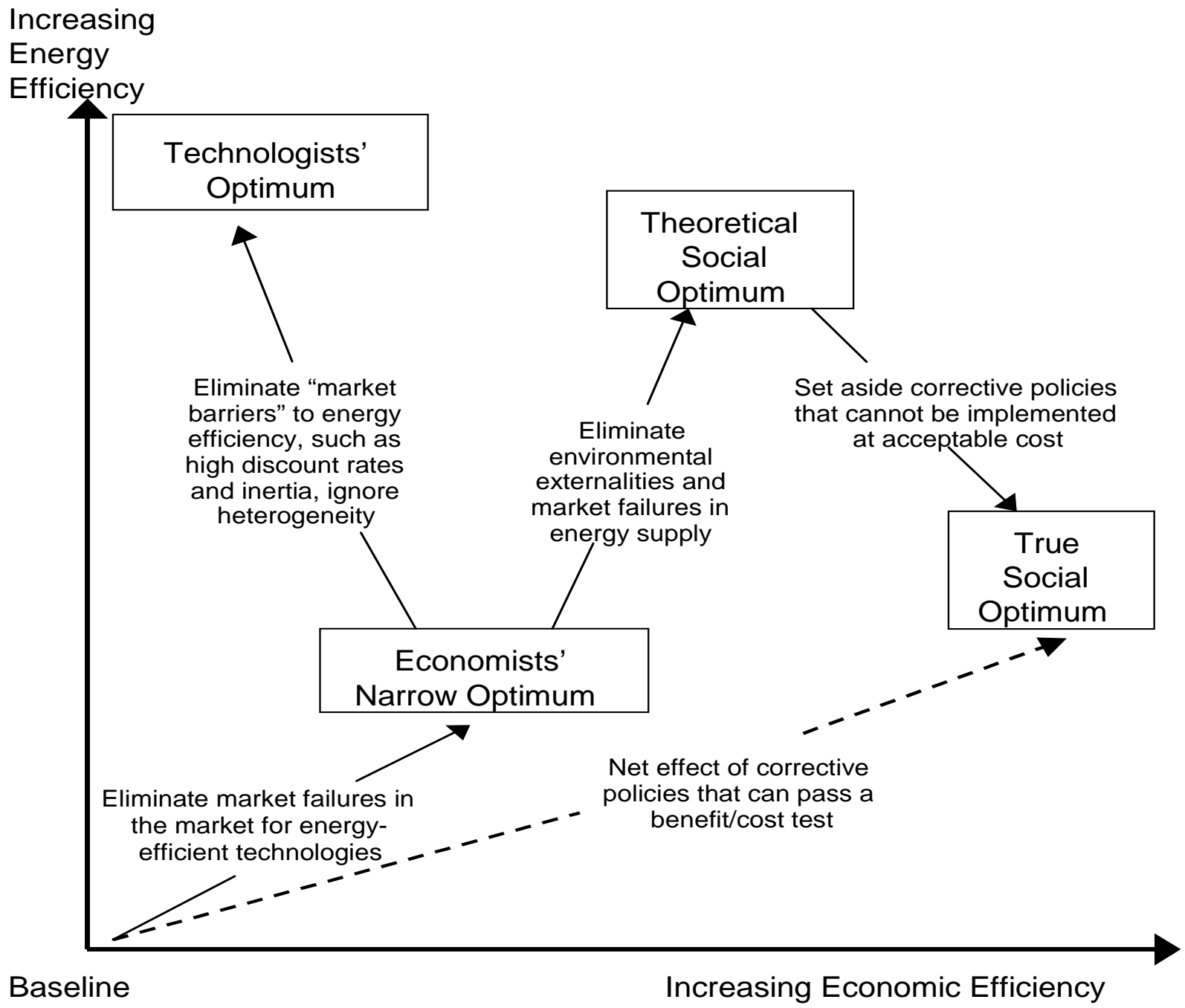




\section{REFERENCES}

All references may be viewed and downloaded from an online bibliographic library available to the public: www.zotero.org/groups/energy efficiency gap.

Abaluck, Jason, and Jonathan Gruber. 2011. "Heterogeneity in Choice Inconsistencies among the Elderly: Evidence from Prescription Drug Plan Choice.” American Economic Review 101 (3): 377-81. http://dx.doi.org/10.1257/aer.101.3.377.

Abrahamse, Wokje, Linda Steg, Charles Vlek, and Talib Rothengatter. 2007. "The Effect of Tailored Information, Goal Setting, and Tailored Feedback on Household Energy Use, Energy-Related Behaviors, and Behavioral Antecedents." Journal of Environmental Psychology 27 (4): 265-76. http://dx.doi.org/10.1016/j.jenvp.2007.08.002.

Akerlof, George A. 1970. “The Market for 'Lemons': Quality Uncertainty and the Market Mechanism." The Quarterly Journal of Economics 84 (3): 488-500. http://dx.doi. org/10.2307/1879431.

__ 1991. "Procrastination and Obedience." American Economic Review 81 (2): 1-19. http://www.jstor.org/stable/2006817.

Alberini, Anna, Silvia Banfi, and Celine Ramseier. 2013. "Energy Efficiency Investments in the Home: Swiss Homeowners and Expectations about Future Energy Prices." Energy Journal 34 (1). http://dx.doi.org/10.5547/01956574.34.1.3.

Alberini, Anna, Markus Bareit, and Massimo Filippini. 2014. Does the Swiss Car Market Reward Fuel Efficient Cars? Evidence from Hedonic Pricing Regressions, Matching and a Regression Discontinuity Design. Working Paper 14/190. Economics Working Paper Series. Zurich, Switzerland: Center of Economic Research at ETH Zurich. www.cer.ethz. ch/research/WP-14-190.pdf.

Allcott, Hunt. 2011a. "Social Norms and Energy Conservation." Journal of Public Economics 95 (9-10): 1082-95. http://dx.doi.org/10.1016/j.jpubeco.2011.03.003.

_ 2011b. "Consumers' Perceptions and Misperceptions of Energy Costs." American Economic Review 101 (3): 98-104. http://dx.doi.org/10.1257/aer.101.3.98.

. 2013. "The Welfare Effects of Misperceived Product Costs: Data and Calibrations from the Automobile Market." American Economic Journal: Economic Policy 5 (3): 30-66. http://dx.doi.org/10.1257/pol.5.3.30. 
Allcott, Hunt, Sendhil Mullainathan, and Dmitry Taubinsky. 2014. "Energy Policy with Externalities and Internalities.” Journal of Public Economics 112 (April): 72-88. http:// dx.doi.org/10.1016/j.jpubeco.2014.01.004.

Allcott, Hunt, and Todd Rogers. 2014. "The Short-Run and Long-Run Effects of Behavioral Interventions: Experimental Evidence from Energy Conservation.” American Economic Review 104 (10): 3003-37. http://dx.doi.org/10.1257/aer.104.10.3003.

Allcott, Hunt, and Dmitry Taubinsky. 2013. The Lightbulb Paradox: Evidence from Two Randomized Experiments. Working Paper 19713. National Bureau of Economic Research. http://www.nber.org/papers/w19713.

Allcott, Hunt, and Nathan Wozny. 2014. "Gasoline Prices, Fuel Economy, and the Energy Paradox." Review of Economics and Statistics 96 (5): 779-95. http://dx.doi.org/10.1162/ REST a 00419.

Alquist, Ron, and Lutz Kilian. 2010. "What Do We Learn from the Price of Crude Oil Futures?” Journal of Applied Econometrics 25 (4): 539-73. http://dx.doi.org/10.1002/ jae.1159.

Ammermueller, Andreas, and Jörn-Steffen Pischke. 2009. "Peer Effects in European Primary Schools: Evidence from the Progress in International Reading Literacy Study." Journal of Labor Economics 27 (3): 315-48. http://dx.doi.org/10.1086/603650.

Anderson, Michael L., and Maximilian Auffhammer. 2013. "Pounds That Kill: The External Costs of Vehicle Weight.” The Review of Economic Studies 81 (2): 535-71. http://dx.doi. org/10.1093/restud/rdt035.

Anderson, Soren T., Ryan Kellogg, and James M. Sallee. 2013. "What Do Consumers Believe about Future Gasoline Prices?” Journal of Environmental Economics and Management 66 (3): 383-403. http://dx.doi.org/10.1016/j.jeem.2013.07.002.

Anderson, Soren T., and Richard G. Newell. 2004. "Information Programs for Technology Adoption: The Case of Energy-Efficiency Audits." Resource and Energy Economics 26 (1): 27-50. http://dx.doi.org/10.1016/j.reseneeco.2003.07.001.

Ansar, Jasmin, and Roger Sparks. 2009. “The Experience Curve, Option Value, and the Energy Paradox." Energy Policy 37 (3): 1012-20. http://dx.doi.org/10.1016/j. enpol.2008.10.037.

Arrow, Kenneth J. 1962. "The Economic Implications of Learning by Doing." Review of Economic Studies 29 (3): 155-73. http://dx.doi.org/10.2307/2295952. 
Attari, Shahzeen Z., Michael L. DeKay, Cliff I. Davidson, and Wändi Bruine de Bruin. 2010. "Public Perceptions of Energy Consumption and Savings." Proceedings of the National Academy of Sciences 107 (37): 16054-59. http://dx.doi.org/10.1073/pnas.1001509107.

Averch, Harvey, and Leland L. Johnson. 1962. "Behavior of the Firm Under Regulatory Constraint." American Economic Review 52 (5): 1052-69. http://www.jstor.org/ stable/ 1812181.

Axsen, Jonn, Dean C. Mountain, and Mark Jaccard. 2009. "Combining Stated and Revealed Choice Research to Simulate the Neighbor Effect: The Case of Hybrid-Electric Vehicles." Resource and Energy Economics 31 (3): 221-38. http://dx.doi.org/10.1016/j. reseneeco.2009.02.001.

Ayres, Ian, Sophie Raseman, and Alice Shih. 2013. "Evidence from Two Large Field Experiments That Peer Comparison Feedback Can Reduce Residential Energy Usage." Journal of Law, Economics, and Organization 29 (5): 992-1022. http://dx.doi. org/10.1093/jleo/ews020.

Baird, Sarah, J. Aislinn Bohren, Craig McIntosh, and Berk Özler. 2014. Designing Experiments to Measure Spillover Effects. Working Paper 14-006. Penn Institute for Economic Research, University of Pennsylvania. http://papers.ssrn.com/sol3/papers.cfm?abstract

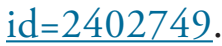

Banerjee, Abhijit V. 1992. "A Simple Model of Herd Behavior.” Quarterly Journal of Economics 107 (3): 797-817. http://dx.doi.org/10.2307/2118364.

Benkard, C. Lanier. 2004. "A Dynamic Analysis of the Market for Wide-Bodied Commercial Aircraft." Review of Economic Studies 71 (3): 581-611. http://dx.doi.org/10.1111/ j.1467-937X.2004.00297.x.

Bento, Antonio M., Shanjun Li, and Kevin Roth. 2012. "Is There an Energy Paradox in Fuel Economy? A Note on the Role of Consumer Heterogeneity and Sorting Bias." Economics Letters 115 (1): 44-48. http://dx.doi.org/10.1016/j.econlet.2011.09.034.

Berndt, Ernst R., Robert S. Pindyck, and Pierre Azoulay. 2003. "Consumption Externalities and Diffusion in Pharmaceutical Markets: Antiulcer Drugs." The Journal of Industrial Economics 51 (2): 243-70. http://dx.doi.org/10.1111/1467-6451.00200.

Berry, Linda G. 1993. "A Review of the Market Penetration of US Residential and Commercial Demand-Side Management Programmes." Energy Policy 21 (1): 53-67. http://dx.doi. org/10.1016/0301-4215(93)90208-W. 
Berry, Linda G., and Michael B. Gettings. 1998. "Realization Rates of the National Energy Audit." In Thermal Performance of the Exterior Envelopes of Buildings VII Conference, 7-11. http://www.ornl.gov/sci/buildings/2012/1998\%20B7\%20papers/058 Berry.pdf.

Berry, Steven T., James Levinsohn, and Ariel Pakes. 1995. "Automobile Prices in Market Equilibrium.” Econometrica 63 (4): 841-90. http://dx.doi.org/10.2307/2171802.

Berry, Steven T., and Joel Waldfogel. 2001. "Do Mergers Increase Product Variety? Evidence from Radio Broadcasting." Quarterly Journal of Economics 116 (3): 1009-25. http:// dx.doi.org/10.1162/00335530152466296.

_ 2010. "Product Quality and Market Size.” Journal of Industrial Economics 58 (1): 1-31. http://dx.doi.org/10.1111/j.1467-6451.2010.00404.x.

Blasnik, Michael. 1990. "Attic Insulation Performance, Air Leakage, and Ventilation: Measured Results in Flat Roof Rowhouses." In ACEEE 1990 Summer Study on Energy Efficiency in Buildings, 9.13-19.22. Pacific Grove, CA. www.proctoreng.com/dnld/92040B.pdf.

Bloom, Nicholas, Benn Eifert, Aprajit Mahajan, David McKenzie, and John Roberts. 2013. "Does Management Matter? Evidence from India." The Quarterly Journal of Economics 128 (1): 1-51. http://dx.doi.org/10.1093/qje/qjo44.

Blumstein, Carl, Betsy Krieg, Lee Schipper, and Carl York. 1980. "Overcoming Social and Institutional Barriers to Energy Conservation.” Energy 5 (4): 355-71. http://dx.doi. org/10.1016/0360-5442(80)90036-5.

Borenstein, Severin. 2005. “The Long-Run Efficiency of Real-Time Electricity Pricing." Energy Journal 26 (3). http://dx.doi.org/10.5547/ISSN0195-6574-EJ-Vol26-No3-5.

Boyes, William J. 1976. “An Empirical Examination of the Averch-Johnson Effect.” Economic Inquiry 14 (1): 25-35. http://dx.doi.org/10.1111/j.1465-7295.1976.tb00374.x.

Brounen, Dirk, and Nils Kok. 2011. "On the Economics of Energy Labels in the Housing Market." Journal of Environmental Economics and Management 62 (2): 166-79. http:// dx.doi.org/10.1016/j.jeem.2010.11.006.

Busse, Meghan R, Christopher R Knittel, and Florian Zettelmeyer. 2013. "Are Consumers Myopic? Evidence from New and Used Car Purchases." American Economic Review 103 (1): 220-56. http://dx.doi.org/10.1257/aer.103.1.220. 
Caird, Sally, Robin Roy, and Horace Herring. 2008. "Improving the Energy Performance of UK Households: Results from Surveys of Consumer Adoption and Use of Low- and Zero-Carbon Technologies.” Energy Efficiency 1 (2): 149-66. http://dx.doi.org/10.1007/ s12053-008-9013-y.

Camilleri, Adrian R., and Richard P. Larrick. 2014. "Metric and Scale Design as Choice Architecture Tools." Journal of Public Policy \& Marketing 33 (1): 108-25. http://dx.doi. org/10.1509/jppm.12.151.

Cardon, James H., and Igal Hendel. 2001. "Asymmetric Information in Health Insurance: Evidence from the National Medical Expenditure Survey." RAND Journal of Economics 32 (3): 408-27. www.jstor.org/stable/2696362.

Case, Anne C., and Lawrence F. Katz. 1991. The Company You Keep: The Effects of Family and Neighborhood on Disadvantaged Youths. Working Paper 3705. National Bureau of Economic Research. http://www.nber.org/papers/w3705.

Chetty, Raj, John N. Friedman, Søren Leth-Petersen, Torben Heien Nielsen, and Tore Olsen. 2014. "Active vs. Passive Decisions and Crowdout in Retirement Savings Accounts: Evidence from Denmark." Quarterly Journal of Economics 129 (3): 1141-1219. http:// dx.doi.org/10.1093/qje/qju013.

Chetty, Raj, Adam Looney, and Kory Kroft. 2009. "Salience and Taxation: Theory and Evidence.” American Economic Review 99 (4): 1145-77. http://dx.doi.org/10.1257/ aer.99.4.1145.

Chiappori, Pierre-Andre, Bruno Jullien, Bernard Salanié, and François Salanié. 2006. "Asymmetric Information in Insurance: General Testable Implications." RAND Journal of Economics 37 (4): 783-98. http://dx.doi.org/10.1111/j.1756-2171.2006.tb00057.x.

Chiappori, Pierre-Andre, and Bernard Salanie. 2000. "Testing for Asymmetric Information in Insurance Markets.” Journal of Political Economy 108 (1): 56-78. http://dx.doi. org/10.1086/262111.

Choi, Jay Pil. 1997. "Herd Behavior, the 'Penguin Effect,' and the Suppression of Informational Diffusion: An Analysis of Informational Externalities and Payoff Interdependency." RAND Journal of Economics 28 (3): 407-25. www.jstor.org/stable/2556022.

Choi, Seok Joon, and Sangsin Kim. 2012. "Why Do Landlords Include Utilities in Rent? Evidence from the 2000 Housing Discrimination Study (HDS) and the 2002 American Housing Survey (AHS).” Journal of Housing Economics 21 (1): 28-40. http://dx.doi. org/10.1016/j.jhe.2012.02.001. 
Cicala, Steve. 2014. When Does Regulation Distort Costs? Lessons from Fuel Procurement in U.S. Electricity Generation. Working Paper 20109. National Bureau of Economic Research. http://www.nber.org/papers/w20109.

Coase, R. H. 1946. “The Marginal Cost Controversy.” Economica 13 (51): 169-82. http:// dx.doi.org/10.2307/2549764.

Cohen, Alma. 2005. "Asymmetric Information and Learning: Evidence from the Automobile Insurance Market." Review of Economics and Statistics 87 (2): 197-207. http://dx.doi. org/10.1162/0034653053970294.

Conley, Timothy G., and Christopher R. Udry. 2010. "Learning about a New Technology: Pineapple in Ghana." American Economic Review 100 (1): 35-69. http://dx.doi. org/10.1257/aer.100.1.35.

Conlisk, John. 1996. "Why Bounded Rationality?” Journal of Economic Literature 34 (2): 669700. http://www.jstor.org/stable/2729218.

Coscelli, Andrea, and Matthew Shum. 2004. "An Empirical Model of Learning and Patient Spillovers in New Drug Entry.” Journal of Econometrics 122 (2): 213-46. http://dx.doi. org/10.1016/j.jeconom.2003.09.002.

Costa, Dora L., and Matthew E. Kahn. 2013. “Energy Conservation 'nudges' and Environmentalist Ideology: Evidence from a Randomized Residential Electricity Field Experiment." Journal of the European Economic Association 11 (3): 680-702. http:// dx.doi.org/10.1111/jeea.12011.

Crawford, Gregory S., and Matthew Shum. 2005. "Uncertainty and Learning in Pharmaceutical Demand." Econometrica 73 (4): 1137-73. http://dx.doi.org/10.1111/j.14680262.2005.00612.x.

Cullen, Joseph. 2013. "Measuring the Environmental Benefits of Wind-Generated Electricity." American Economic Journal: Economic Policy 5 (4): 107-33. http://dx.doi.org/10.1257/ pol.5.4.107.

Davis, Lucas W. 2012. "Evaluating the Slow Adoption of Energy Efficient Investments: Are Renters Less Likely to Have Energy Efficient Appliances?” In The Design and Implementation of U.S. Climate Policy, edited by Don Fullerton and Catherine Wolfram. University of Chicago Press. www.nber.org/chapters/c12130.pdf. 
Davis, Lucas W., Alan Fuchs, and Paul Gertler. 2014. "Cash for Coolers: Evaluating a LargeScale Appliance Replacement Program in Mexico." American Economic Journal: Economic Policy 6 (4): 207-38. http://dx.doi.org/10.1257/pol.6.4.207.

Davis, Lucas W., and Erich Muehlegger. 2010. "Do Americans Consume Too Little Natural Gas? An Empirical Test of Marginal Cost Pricing." RAND Journal of Economics 41 (4): 791-810. http://dx.doi.org/10.1111/j.1756-2171.2010.00121.x.

De Almeida, Edmar Luiz Fagundes. 1998. "Energy Efficiency and the Limits of Market Forces: The Example of the Electric Motor Market in France.” Energy Policy 26 (8): 643-53. http://dx.doi.org/10.1016/S0301-4215(98)00023-8.

DeCanio, Stephen J. 1993. "Barriers within Firms to Energy-Efficient Investments." Energy Policy 21 (9): 906-14. http://dx.doi.org/10.1016/0301-4215(93)90178-I.

DellaVigna, Stefano, and Ulrike Malmendier. 2006. "Paying Not to Go to the Gym." American Economic Review 96 (3): 694-719. http://dx.doi.org/10.1257/aer.96.3.694.

Diederen, Paul, Frank van Tongeren, and Hennie van der Veen. 2003. "Returns on Investments in Energy-Saving Technologies Under Energy Price Uncertainty in Dutch Greenhouse Horticulture." Environmental and Resource Economics 24 (4): 379-94. http://dx.doi. org/10.1023/A:1023617318184.

Dinner, Isaac, Eric J. Johnson, Daniel G. Goldstein, and Kaiya Liu. 2011. "Partitioning Default Effects: Why People Choose Not to Choose.” Journal of Experimental Psychology: Applied 17 (4): 332-41. http://dx.doi.org/10.1037/a0024354.

Dixit, Avinash K., and Robert S. Pindyck. 1994. Investment under Uncertainty. Princeton University Press.

Dubin, Jeffrey A., and Steven E. Henson. 1988. "An Engineering/Econometric Analysis of Seasonal Energy Demand and Conservation in the Pacific Northwest." Journal of Business o Economic Statistics 6 (1): 121-34. http://dx.doi.org/10.2307/1391425.

Dubin, Jeffrey A., and Daniel L. McFadden. 1984. "An Econometric Analysis of Residential Electric Appliance Holdings and Consumption.” Econometrica 52 (2): 345-62. http:// dx.doi.org/10.2307/1911493.

Dubin, Jeffrey A., Allen K. Miedema, and Ram V. Chandran. 1986. "Price Effects of EnergyEfficient Technologies: A Study of Residential Demand for Heating and Cooling." RAND Journal of Economics 17 (3): 310-25. www.jstor.org/stable/2555713. 
Duflo, Esther, and Emmanuel Saez. 2002. "Participation and Investment Decisions in a Retirement Plan: The Influence of Colleagues' Choices.” Journal of Public Economics 85 (1): 121-48. http://dx.doi.org/10.1016/S0047-2727(01)00098-6.

Eichholtz, Piet, Nils Kok, and John Quigley. 2010. "Doing Well by Doing Good? Green Office Buildings.” American Economic Review 100 (5): 2494-2511. http://dx.doi.org/10.1257/ aer.100.5.2492.

- 2012. "The Economics of Green Building." Review of Economics and Statistics 95 (1): 50-63. http://dx.doi.org/10.1162/REST a 00291.

Emerick, Kyle. 2014. "The Efficiency of Trading in Social Networks: Experimental Measures from India." UC Berkeley. www.ocf.berkeley.edu/ kemerick/Emerick_Networks.pdf.

Fama, Eugene F., and Kenneth R. French. 2004. "The Capital Asset Pricing Model: Theory and Evidence." Journal of Economic Perspectives 18 (3): 25-46. http://www.jstor.org/ stable/3216805.

Faruqui, Ahmad, and Sanem Sergici. 2011. "Dynamic Pricing of Electricity in the MidAtlantic Region: Econometric Results from the Baltimore Gas and Electric Company Experiment." Journal of Regulatory Economics 40 (1): 82-109. http://dx.doi.org/10.1007/ s11149-011-9152-5.

Finkelstein, Amy, and James Poterba. 2004. "Adverse Selection in Insurance Markets: Policyholder Evidence from the U.K. Annuity Market.” Journal of Political Economy 112 (1): 183-208. http://dx.doi.org/10.1086/379936.

—_. 2006. Testing for Asymmetric Information Using "Unused Observables" in Insurance Markets: Evidence from the U.K. Annuity Market. Working Paper 12112. National Bureau of Economic Research. http://www.nber.org/papers/w12112.

Fischer, Carolyn. 2010. Imperfect Competition, Consumer Behavior, and the Provision of Fuel Efficiency in Light-Duty Vehicles. Discussion Paper 10-60. Washington, D.C.: Resources For the Future. www.rff.org/Publications/Pages/PublicationDetails. aspx?PublicationID=21431.

Fisher, Anthony C., and Michael H. Rothkopf. 1989. "Market Failure and Energy Policy: A Rationale for Selective Conservation.” Energy Policy 17 (4): 397-406. http://dx.doi. org/10.1016/0301-4215(89)90010-4. 
Fleiter, Tobias, Joachim Schleich, and Ployplearn Ravivanpong. 2012. "Adoption of EnergyEfficiency Measures in SMEs-An Empirical Analysis Based on Energy Audit Data from Germany." Energy Policy 51 (December): 863-75. http://dx.doi.org/10.1016/j. enpol.2012.09.041.

Foster, Andrew D., and Mark R. Rosenzweig. 1995. "Learning by Doing and Learning from Others: Human Capital and Technical Change in Agriculture." Journal of Political Economy 103 (6): 1176-1209. www.jstor.org/stable/2138708.

2010. "Microeconomics of Technology Adoption." Annual Review of Economics 2 (1): 395-424. http://dx.doi.org/10.1146/annurev.economics.102308.124433.

Fowlie, Meredith. 2010. "Emissions Trading, Electricity Restructuring, and Investment in Pollution Abatement." American Economic Review 100 (3): 837-69. http://dx.doi. org/10.1257/aer.100.3.837.

Fowlie, Meredith, Michael Greenstone, and Catherine Wolfram. 2014. "An Experimental Evaluation of the Weatherization Assistance Program.” In preparation.

Gately, Dermot. 1980. "Individual Discount Rates and the Purchase and Utilization of EnergyUsing Durables: Comment.” Bell Journal of Economics 11 (1): 373-74. http://dx.doi. org/10.2307/3003422.

Gilbert, Richard J., and David M. Newbery. 1994. “The Dynamic Efficiency of Regulatory Constitutions." RAND Journal of Economics 25 (4): 538-54. www.jstor.org/ stable/2555974.

Gillingham, Kenneth, Matthew Harding, and David Rapson. 2012. "Split Incentives in Residential Energy Consumption.” Energy Journal 33 (2): 37-62. http://dx.doi. org/10.5547/01956574.33.2.3.

Gillingham, Kenneth, Richard G. Newell, and Karen L. Palmer. 2009. "Energy Efficiency Economics and Policy." Annual Review of Resource Economics 1 (June): 597-620. http:// dx.doi.org/10.1146/annurev.resource.102308.124234.

Gillingham, Kenneth, and Karen L. Palmer. 2014. "Bridging the Energy Efficiency Gap: Policy Insights from Economic Theory and Empirical Evidence.” Review of Environmental Economics and Policy 8 (1): 18-38. http://dx.doi.org/10.1093/reep/ret021.

Giraudet, Louis-Gaëtan, and Sébastien Houde. 2014. Double Moral Hazard and the Energy Efficiency Gap. Working Paper 9. Berkeley, California: Evidence for Action on Energy Efficiency (E2e). http://e2e.haas.berkeley.edu/pdf/workingpapers/WP009.pdf. 
Goldberg, Pinelopi Koujianou. 1998. "The Effects of the Corporate Average Fuel Efficiency Standards in the US." Journal of Industrial Economics 46 (1): 1-33. http://dx.doi. org/10.1111/1467-6451.00059.

Goldstein, Noah J., Robert B. Cialdini, and Vladas Griskevicius. 2008. "A Room with a Viewpoint: Using Social Norms to Motivate Environmental Conservation in Hotels." Journal of Consumer Research 35 (3): 472-82. http://dx.doi.org/10.1086/586910.

Granade, Hannah Choi, John Creyts, Anton Derkach, Philip Farese, Scott Nyquist, and Ken Ostrowski. 2009. Unlocking Energy Efficiency in the U.S. Economy. McKinsey \& Company. www.mckinsey.com/client service/electric power and natural gas/latest thinking/ unlocking energy efficiency in the us economy.

Greene, David L. 2011. "Uncertainty, Loss Aversion, and Markets for Energy Efficiency.” Energy Economics 33 (4): 608-16. http://dx.doi.org/10.1016/j.eneco.2010.08.009.

Greene, David L., David H. Evans, and John Hiestand. 2013. "Survey Evidence on the Willingness of U.S. Consumers to Pay for Automotive Fuel Economy." Energy Policy 61 (October): 1539-50. http://dx.doi.org/10.1016/j.enpol.2013.05.050.

Greening, Lorna A., David L. Greene, and Carmen Difiglio. 2000. "Energy Efficiency and Consumption - the Rebound Effect - a Survey." Energy Policy 28 (6-7): 389-401. http:// dx.doi.org/10.1016/S0301-4215(00)00021-5.

Griliches, Zvi. 1957. "Hybrid Corn: An Exploration in the Economics of Technological Change.” Econometrica 25 (4): 501-22. http://dx.doi.org/10.2307/1905380.

— 1992. "The Search for R\&D Spillovers." Scandinavian Journal of Economics 94 (Supplement: Proceedings of a Symposium on Productivity Concepts and Measurement Problems: Welfare, Quality and Productivity in the Service Industries): S29-47. http:// dx.doi.org/10.2307/3440244.

Grubb, Michael D. 2009. "Selling to Overconfident Consumers." American Economic Review 99 (5): 1770-1807. http://dx.doi.org/10.1257/aer.99.5.1770.

Hall, Bronwyn H, Jacques Mairesse, and Pierre Mohnen. 2010. "Measuring the Returns to R \& D." In Handbook of the Economics of Innovation, edited by Bronwyn H. Hall and Nathan Rosenberg, 2:1033-82. Amsterdam and Boston: Elsevier B.V. http://dx.doi. org/10.1016/S0169-7218(10)02008-3. 
Hall, Bronwyn H., and Nathan Rosenberg, eds. 2010. Handbook of the Economics of Innovation. Amsterdam and Boston: Elsevier. www.sciencedirect.com/sciencel handbooks/22108807/2/supp/C.

Hall, Robert. 1997. The Inkjet Aftermarket: An Economic Analysis. Stanford University. http:// www.stanford.edu/ - rehall/Inkjet\%20Aftermarket\%201997.pdf.

Hardisty, David J., Kirstin C. Appelt, and Elke U. Weber. 2013. "Good or Bad, We Want It Now: Fixed-Cost Present Bias for Gains and Losses Explains Magnitude Asymmetries in Intertemporal Choice." Journal of Behavioral Decision Making 26 (4): 348-61. http:// dx.doi.org/10.1002/bdm.1771.

Hassett, Kevin A., and Gilbert E. Metcalf. 1993. "Energy Conservation Investment: Do Consumers Discount the Future Correctly?” Energy Policy 21 (6): 710-16. http://dx.doi. org/10.1016/0301-4215(93)90294-P.

Hausman, Jerry A. 1979. "Individual Discount Rates and the Purchase and Utilization of Energy-Using Durables." Bell Journal of Economics 10 (1): 33. http://dx.doi. org/10.2307/3003318.

Hausman, Jerry A., and Paul L. Joskow. 1982. "Evaluating the Costs and Benefits of Appliance Efficiency Standards." American Economic Review 72 (2): 220-25. www.jstor.org/ stable/1802332.

Heath, Chip, Richard P. Larrick, and George Wu. 1999. "Goals as Reference Points." Cognitive Psychology 38 (1): 79-109. http://dx.doi.org/10.1006/cogp.1998.0708.

Helfand, Gloria, and Ann Wolverton. 2011. "Evaluating the Consumer Response to Fuel Economy: A Review of the Literature." International Review of Environmental and Resource Economics 5 (2): 103-46. http://dx.doi.org/10.1561/101.00000040.

Heutel, Garth, and Erich Muehlegger. 2014. "Consumer Learning and Hybrid Vehicle Adoption." Environmental and Resource Economics, August. http://dx.doi.org/10.1007/ s10640-014-9819-3.

Hirst, Eric. 1986. "Actual Energy Savings after Retrofit: Electrically Heated Homes in the Pacific Northwest." Energy 11 (3): 299-308. http://dx.doi.org/10.1016/03605442(86)90088-5.

Hossain, Tanjim, and John Morgan. 2006. “...Plus Shipping and Handling: Revenue (Non) Equivalence in Field Experiments on eBay." Advances in Economic Analysis \& Policy 5 (2). http://dx.doi.org/10.2202/1538-0637.1429. 
Houde, Sébastien. 2014a. How Consumers Respond to Environmental Certification and the Value of Energy Information. Working Paper 20019. National Bureau of Economic Research. http://www.nber.org/papers/w20019.

2014b. Bunching with the Stars: How Firms Respond to Environmental Certification. Working Paper. University of Maryland. http://terpconnect.umd.edu/-shoude/ EnergyStarFirmsHoude May2014.pdf.

Howarth, Richard B., and Bo Andersson. 1993. "Market Barriers to Energy Efficiency." Energy Economics 15 (4): 262-72. http://dx.doi.org/10.1016/0140-9883(93)90016-K.

Howarth, Richard B., Brent M. Haddad, and Bruce Paton. 2000. "The Economics of Energy Efficiency: Insights from Voluntary Participation Programs.” Energy Policy 28 (6-7): 477-86. http://dx.doi.org/10.1016/S0301-4215(00)00026-4.

Huntington, Hillard G. 2011. "The Policy Implications of Energy-Efficiency Cost Curves.” Energy Journal 32 (Special Issue: Strategies for Mitigating Climate Change Through Energy Efficiency: A Multi-Model Perspective): 7-21. http://dx.doi.org/10.5547/ ISSN0195-6574-EJ-Vol32-NoSI-2.

IEA. 2007. Mind the Gap: Quantifying Principal-Agent Problems in Energy Efficiency. Paris: International Energy Agency. www.iea.org/publications/freepublications/publication/ mind the gap.pdf.

IMF. 2013. Energy Subsidy Reform: Lessons and Implications. Washington, D.C.: International Monetary Fund. www.imf.org/external/np/pp/eng/2013/012813.pdf.

Irwin, Douglas A., and Peter J. Klenow. 1994. "Learning-by-Doing Spillovers in the Semiconductor Industry." Journal of Political Economy 102 (6): 1200-1227. www.jstor. org/stable/2138784.

Ito, Koichiro. 2014. "Do Consumers Respond to Marginal or Average Price? Evidence from Nonlinear Electricity Pricing." American Economic Review 104 (2): 537-63. http:// dx.doi.org/10.1257/aer.104.2.537.

Ito, Koichiro, Takanori Ida, and Makoto Tanaka. 2014. "The Persistence of Moral Suasion and Monetary Incentives: Experimental Evidence from Energy Demand.” http://people. bu.edu/ito/Ito Ida Tanaka Moral Money.pdf.

Jaffe, Adam B., Richard G. Newell, and Robert N. Stavins. 2002. "Environmental Policy and Technological Change." Environmental and Resource Economics 22 (1-2): 41-70. http:// dx.doi.org/10.1023/A:1015519401088. 
_ 2005. "A Tale of Two Market Failures: Technology and Environmental Policy." Ecological Economics 54 (2-3): 164-74. http://dx.doi.org/10.1016/j. ecolecon.2004.12.027.

Jaffe, Adam B., and Robert N. Stavins. 1994a. "The Energy Paradox and the Diffusion of Conservation Technology." Resource and Energy Economics 16 (2): 91-122. http://dx.doi. org/10.1016/0928-7655(94)90001-9.

1994b. “The Energy-Efficiency Gap: What Does It Mean?” Energy Policy 22 (10): 804-10. http://dx.doi.org/10.1016/0301-4215(94)90138-4.

_ _ 1995. "Dynamic Incentives of Environmental Regulations: The Effects of Alternative Policy Instruments on Technology Diffusion." Journal of Environmental Economics and Management 29 (3): 43-63. http://dx.doi.org/10.1006/jeem.1995.1060.

Janakiraman, Ramkumar, Catarina Sismeiro, and Shantanu Dutta. 2009. "Perception Spillovers Across Competing Brands: A Disaggregate Model of How and When." Journal of Marketing Research 46 (4): 467-81. http://dx.doi.org/10.1509/jmkr.46.4.467.

Jessoe, Katrina, and David Rapson. 2014. "Knowledge Is (Less) Power: Experimental Evidence from Residential Energy Use.” American Economic Review 104 (4): 1417-38. http:// dx.doi.org/10.1257/aer.104.4.1417.

Jessoe, Katrina, David Rapson, and Jeremy Blair Smith. 2014. "Towards Understanding the Role of Price in Residential Electricity Choices: Evidence from a Natural Experiment." Journal of Economic Behavior \& Organization 107 (Part A): 191-208. http://dx.doi. org/10.1016/j.jebo.2014.03.009.

Joskow, Paul L., and Donald B. Marron. 1993. "What Does Utility-Subsidized Energy Efficiency Really Cost?” Science 260 (5106): 281-370. http://dx.doi.org/10.1126/ science.260.5106.281.

Joskow, Paul L., and Catherine D. Wolfram. 2012. "Dynamic Pricing of Electricity." American Economic Review 102 (3): 381-85. http://dx.doi.org/10.1257/aer.102.3.381.

Jovanovic, Boyan. 1982. "Truthful Disclosure of Information." Bell Journal of Economics 13 (1): 36-44. http://dx.doi.org/10.2307/3003428.

Kahneman, Daniel, and Amos Tversky. 1979. "Prospect Theory: An Analysis of Decision under Risk.” Econometrica 47 (2): 263-91. http://dx.doi.org/10.2307/1914185. 
Kamien, Morton I., and Nancy L. Schwartz. 1982. Market Structure and Innovation. Cambridge University Press.

Koomey, Jonathan G., Alan H. Sanstad, and Leslie J. Shown. 1996. "Energy-Efficient Lighting: Market Data, Market Imperfections, and Policy Success." Contemporary Economic Policy 14 (3): 98-111. http://dx.doi.org/10.1111/j.1465-7287.1996.tb00627.x.

Köszegi, Botond, and Matthew Rabin. 2006. "A Model of Reference-Dependent Preferences." Quarterly Journal of Economics 121 (4): 1133-65. http://dx.doi.org/10.1093/ qje/121.4.1133.

Laibson, David. 1997. "Golden Eggs and Hyperbolic Discounting." The Quarterly Journal of Economics 112 (2): 443-77. http://dx.doi.org/10.1162/003355397555253.

Langer, Ashley, and Nathan H. Miller. 2012. "Automakers' Short-Run Responses to Changing Gasoline Prices.” Review of Economics and Statistics 95 (4): 1198-1211. http://dx.doi. org/10.1162/REST a 00297.

Larrick, Richard P., and Jack B. Soll. 2008. “The MPG Illusion.” Science 320 (5883): 1593-94. http://dx.doi.org/10.1126/science.1154983.

Levinson, Arik, and Scott Niemann. 2004. "Energy Use by Apartment Tenants When Landlords Pay for Utilities.” Resource and Energy Economics 26 (1): 51-75. http://dx.doi. org/10.1016/S0928-7655(03)00047-2.

Levitt, Steven D., John A. List, and Chad Syverson. 2013. “Toward an Understanding of Learning by Doing: Evidence from an Automobile Assembly Plant." Journal of Political Economy 121 (4): 643-81. http://dx.doi.org/10.1086/671137.

Lewis, Gregory. 2011. "Asymmetric Information, Adverse Selection and Online Disclosure: The Case of eBay Motors." American Economic Review 101 (4): 1535-46. http://dx.doi. org/10.1257/aer.101.4.1535.

Lieberman, Marvin B. 1984. "The Learning Curve and Pricing in the Chemical Processing Industries." RAND Journal of Economics 15 (2): 213-28. www.jstor.org/stable/2555676.

Lim, Claire, and Ali Yurukoglu. 2014. "Dynamic Natural Monopoly Regulation: Time Inconsistency, Asymmetric Information, and Political Environments.” http://web. stanford.edu/-ayurukog/main infrastructure.pdf.

Loewenstein, George, and Richard H Thaler. 1989. “Anomalies: Intertemporal Choice.” Journal of Economic Perspectives 3 (4): 181-93. http://dx.doi.org/10.1257/jep.3.4.181. 
Löfgren, Åsa, Katrin Millock, and Céline Nauges. 2008. "The Effect of Uncertainty on Pollution Abatement Investments: Measuring Hurdle Rates for Swedish Industry." Resource and Energy Economics 30 (4): 475-91. http://dx.doi.org/10.1016/j.reseneeco.2008.09.002.

Manski, Charles F. 1993a. "Dynamic Choice in Social Settings: Learning from the Experiences of Others." Journal of Econometrics 58 (1-2): 121-36. http://dx.doi.org/10.1016/03044076(93)90115-L.

1993b. "Identification of Endogenous Social Effects: The Reflection Problem." The Review of Economic Studies 60 (3): 531-42. http://dx.doi.org/10.2307/2298123.

—_. 2004. "Measuring Expectations." Econometrica 72 (5): 1329-76. http://dx.doi. org/10.1111/j.1468-0262.2004.00537.x.

Maruejols, Lucie, and Denise Young. 2011. "Split Incentives and Energy Efficiency in Canadian Multi-Family Dwellings.” Energy Policy 39 (6): 3655-68. http://dx.doi.org/10.1016/j. enpol.2011.03.072.

Mau, Paulus, Jimena Eyzaguirre, Mark Jaccard, Colleen Collins-Dodd, and Kenneth Tiedemann. 2008. "The 'Neighbor Effect': Simulating Dynamics in Consumer Preferences for New Vehicle Technologies." Ecological Economics 68 (1-2): 504-16. http://dx.doi.org/10.1016/j.ecolecon.2008.05.007.

McDonald, Robert, and Daniel Siegel. 1986. "The Value of Waiting to Invest." Quarterly Journal of Economics 101 (4): 707-27. http://dx.doi.org/10.2307/1884175.

Metcalf, Gilbert E. 1994. "Economics and Rational Conservation Policy." Energy Policy 22 (10): 819-25. http://dx.doi.org/10.1016/0301-4215(94)90140-6.

Metcalf, Gilbert E., and Kevin A. Hassett. 1999. "Measuring the Energy Savings from Home Improvement Investments: Evidence from Monthly Billing Data." Review of Economics and Statistics 81 (3): 516-28. http://dx.doi.org/10.1162/003465399558274.

Muller, Nicholas Z., and Robert Mendelsohn. 2009. "Efficient Pollution Regulation: Getting the Prices Right." American Economic Review 99 (5): 1714-39. http://dx.doi. org/10.1257/aer.99.5.1714.

Murphy, Rose, and Mark Jaccard. 2011. "Energy Efficiency and the Cost of GHG Abatement: A Comparison of Bottom-up and Hybrid Models for the US." Energy Policy 39 (11): 7146-55. http://dx.doi.org/10.1016/j.enpol.2011.08.033. 
Murtishaw, Scott, and Jayant Sathaye. 2006. Quantifying the Effect of the Principal-Agent Problem on US Residential Energy Use. LBNL-59773. Berkeley, California: Lawrence Berkeley National Laboratory. http://escholarship.org/uc/item/6f14t11t\#page-1.

Myers, Erica. 2013. Asymmetric Information in Residential Rental Markets: Implications for the Energy Efficiency Gap. Working Paper 246. Energy Institute at Haas, UC Berkeley. http://ei.haas.berkeley.edu/pdf/working_papers/WP246.pdf.

Nadel, Steven, and Kenneth Keating. 1991. Engineering Estimates vs. Impact Evaluation Results: How Do They Compare and Why? Research Report U915. Washington, D.C.: American Council for an Energy-Efficient Economy. www.aceee.org/research-report/u915.

Narayanan, Sridhar, and Harikesh S. Nair. 2013. "Estimating Causal Installed-Base Effects: A Bias-Correction Approach.” Journal of Marketing Research 50 (1): 70-94. http://dx.doi. org/10.1509/jmr.11.0183.

National Research Council. 2010. Hidden Costs of Energy: Unpriced Consequences of Energy Production and Use. Washington, D.C.: The National Academies Press. www.nap.edu/ catalog.php?.record id=12794.

Naughton, Michael C. 1986. "The Efficiency and Equity Consequences of Two-Part Tariffs in Electricity Pricing." Review of Economics and Statistics 68 (3): 406-14. http://dx.doi. org/10.2307/1926017.

Newell, Richard G., Adam B. Jaffe, and Robert N. Stavins. 1999. "The Induced Innovation Hypothesis and Energy-Saving Technological Change.” The Quarterly Journal of Economics 114 (3): 941-75. http://dx.doi.org/10.1162/003355399556188.

Newell, Richard G., and Juha Siikamäki. 2014. "Nudging Energy Efficiency Behavior: The Role of Information Labels." Journal of the Association of Environmental and Resource Economists 1 (4): 555-98. http://dx.doi.org/10.1086/679281.

Nordhaus, William. 2011. "Designing a Friendly Space for Technological Change to Slow Global Warming." Energy Economics 33 (4): 665-73. http://dx.doi.org/10.1016/j. eneco.2010.08.005.

O’Donoghue, Ted, and Matthew Rabin. 2006. “Optimal Sin Taxes.” Journal of Public Economics 90 (10-11): 1825-49. http://dx.doi.org/10.1016/j.jpubeco.2006.03.001.

Ostertag, Katrin. 2003. No-Regret Potentials in Energy Conservation: An Analysis of Their Relevance, Size and Determinants. Series of the Fraunhofer Institute for Systems and Innovation Research 15. Heidelberg, Germany: Physica-Verlag. 
Palmer, Karen L., Margaret Walls, and Todd Gerarden. 2012. Borrowing to Save Energy: An Assessment of Energy-Effciency Financing Programs. Washington, D.C.: Resources for the Future. http://www.rff.org/RFF/Documents/RFF-Rpt-Palmeretal\%20EEFinancing.pdf.

Palmer, Karen L., Margaret Walls, Hal Gordon, and Todd Gerarden. 2013. "Assessing the Energy-Efficiency Information Gap: Results from a Survey of Home Energy Auditors." Energy Efficiency 6 (2): 271-92. http://dx.doi.org/10.1007/s12053-012-9178-2.

Papineau, Maya. 2014. Energy Codes and the Landlord-Tenant Problem. Working Paper. Carleton University. https://drive.google.com/viewerng/r? a=v\&pid=sites\&srcid=ZGVmYXVsdGR vbWFpbnxtYXlhcGFwaW51YXV8Z3g6NGM4Y2I2ODVjNGUwNzlmMQ.

Parry, Ian W. H, Margaret Walls, and Winston Harrington. 2007. "Automobile Externalities and Policies." Journal of Economic Literature 45 (2): 373-99. http://dx.doi.org/10.1257/ jel.45.2.373.

Petrin, Amil. 2002. "Quantifying the Benefits of New Products: The Case of the Minivan." Journal of Political Economy 110 (4): 705-29. http://dx.doi.org/10.1086/340779.

Phillips, Yvonne. 2012. "Landlords versus Tenants: Information Asymmetry and Mismatched Preferences for Home Energy Efficiency.” Energy Policy 45 (June): 112-21. http://dx.doi. org/10.1016/j.enpol.2012.01.067.

Popp, David. 2002. "Induced Innovation and Energy Prices." American Economic Review 92 (1): 160-80. http://dx.doi.org/10.1257/000282802760015658.

Popp, David, Richard G. Newell, and Adam B. Jaffe. 2010. "Energy, the Environment, and Technological Change." In Handbook of the Economics of Innovation, edited by Bronwyn H. Hall and Nathan Rosenberg, 2:873-937. Amsterdam and Boston: Elsevier. http:// dx.doi.org/10.1016/S0169-7218(10)02005-8.

Puller, Steven L., and Jeremy West. 2013. "Efficient Retail Pricing in Electricity and Natural Gas Markets.” American Economic Review 103 (3): 350-55. http://dx.doi.org/10.1257/ aer.103.3.350.

Rapson, David. 2014. "Durable Goods and Long-Run Electricity Demand: Evidence from Air Conditioner Purchase Behavior." Journal of Environmental Economics and Management 68 (1): 141-60. http://dx.doi.org/10.1016/j.jeem.2014.04.003.

Rohdin, P., and P. Thollander. 2006. "Barriers to and Driving Forces for Energy Efficiency in the Non-Energy Intensive Manufacturing Industry in Sweden.” Energy 31 (12): 183644. http://dx.doi.org/10.1016/j.energy.2005.10.010. 
Sallee, James M. 2013. Rational Inattention and Energy Efficiency. Working Paper 19545. National Bureau of Economic Research. http://www.nber.org/papers/w19545.

Sallee, James M., and Joel Slemrod. 2012. "Car Notches: Strategic Automaker Responses to Fuel Economy Policy." Journal of Public Economics 96 (11-12): 981-99. http://dx.doi. org/10.1016/j.jpubeco.2012.06.005.

Sallee, James M., Sarah E. West, and Wei Fan. 2009. "Consumer Valuation of Fuel Economy: A Microdata Approach." Proceedings of the Annual Conference on Taxation, June, 254-59.

Sanstad, Alan H., Carl Blumstein, and Steven E. Stoft. 1995. "How High Are Option Values in Energy-Efficiency Investments?” Energy Policy 23 (9): 739-43. http://dx.doi. org/10.1016/0301-4215(95)00065-Q.

Sanstad, Alan H., W. Michael Hanemann, and Maximilian Auffhammer. 2006. "End-Use Energy Efficiency in a 'post- Carbon' California Economy.” In Managing Greenhouse Gas Emissions in California, edited by W. Michael Hanemann and Alexander E. Farrell. Berkeley, CA: The California Climate Change Center at UC Berkeley.

Sanstad, Alan H., and Richard B. Howarth. 1994. "Consumer Rationality and Energy Efficiency." In Proceedings of the ACEEE, 1.175-1.183. https://www.aceee.org/files/ proceedings/1994/data/papers/SS94 Panel1 Paper21.pdf.

Schleich, Joachim. 2009. "Barriers to Energy Efficiency: A Comparison across the German Commercial and Services Sector.” Ecological Economics 68 (7): 2150-59. http://dx.doi. org/10.1016/j.ecolecon.2009.02.008.

Schultz, P. Wesley, Jessica M. Nolan, Robert B. Cialdini, Noah J. Goldstein, and Vladas Griskevicius. 2007. "The Constructive, Destructive, and Reconstructive Power of Social Norms.” Psychological Science 18 (5): 429-34. http://dx.doi.org/10.1111/j.14679280.2007.01917.x.

Sebold, Frederick, and Eric Fox. 1985. "Realized Savings from Residential Conservation Activity." The Energy Journal 6 (2): 73-88. http://dx.doi.org/10.5547/ISSN0195-6574EJ-Vol6-No2-6.

Shaked, Avner, and John Sutton. 1987. "Product Differentiation and Industrial Structure." Journal of Industrial Economics 36 (2): 131-46. http://dx.doi.org/10.2307/2098408.

Shama, Avraham. 1983. "Energy Conservation in US Buildings: Solving the High Potential/low Adoption Paradox from a Behavioural Perspective.” Energy Policy 11 (2): 148-67. http:// dx.doi.org/10.1016/0301-4215(83)90027-7. 
Sharma, Dhruv N. 2011. "Economic Efficiency and Distributional Impacts of Policies for Increasing U.S. Residential Insulation.” Ph.D., Stanford University. http://search. proquest.com/docview/907105902/abstract?accountid=11311.

Sorrell, Steve, John Dimitropoulos, and Matt Sommerville. 2009. "Empirical Estimates of the Direct Rebound Effect: A Review.” Energy Policy 37 (4): 1356-71. http://dx.doi. org/10.1016/j.enpol.2008.11.026.

Sorrell, Steve, Eoin O'Malley, Joachim Schleich, and Sue Scott. 2004. The Economics of Energy Efficiency: Barriers to Cost-Effective Investment. Chapter 5, "Standing on a Burning Platform: Barriers to Energy Efficiency in the UK Brewing Industry," 349. Cheltenham: Edward Elgar.

Spann, Robert M. 1974. "Rate of Return Regulation and Efficiency in Production: An Empirical Test of the Averch-Johnson Thesis." Bell Journal of Economics and Management Science 5 (1): 38-52. http://dx.doi.org/10.2307/3003091.

Spence, A. Michael. 1975. “Monopoly, Quality, and Regulation.” Bell Journal of Economics 6 (2): 417-29. http://dx.doi.org/10.2307/3003237.

1976. "Product Selection, Fixed Costs, and Monopolistic Competition." The Review of Economic Studies 43 (2): 217-35. http://dx.doi.org/10.2307/2297319.

— 1981. “The Learning Curve and Competition.” Bell Journal of Economics 12 (1): 49-70. http://dx.doi.org/10.2307/3003508.

Sutherland, Ronald J. 1991. "Market Barriers to Energy-Efficiency Investments.” Energy Journal 12 (3): 15-34. www.jstor.org/stable/41322426.

Ternes, Mark P., and Michael B. Gettings. 2008. Analyses to Verify and Improve the Accuracy of the Manufactured Home Energy Audit (MHEA). Oak Ridge National Laboratory (ORNL). http://weatherization.ornl.gov/pdfs/ORNL CON-506.pdf.

Thaler, Richard. 1985. "Mental Accounting and Consumer Choice." Marketing Science 4 (3): 199-214. www.jstor.org/stable/183904.

Thollander, Patrik, Maria Danestig, and Patrik Rohdin. 2007. "Energy Policies for Increased Industrial Energy Efficiency: Evaluation of a Local Energy Programme for Manufacturing SMEs.” Energy Policy 35 (11): 5774-83. http://dx.doi.org/10.1016/j. enpol.2007.06.013. 
Thollander, Patrik, and Mikael Ottosson. 2008. "An Energy Efficient Swedish Pulp and Paper Industry - Exploring Barriers to and Driving Forces for Cost-Effective Energy Efficiency Investments." Energy Efficiency 1 (1): 21-34. http://dx.doi.org/10.1007/s12053-0072001-7.

Thornton, Rebecca Achee, and Peter Thompson. 2001. "Learning from Experience and Learning from Others: An Exploration of Learning and Spillovers in Wartime Shipbuilding." American Economic Review 91 (5): 1350-68. www.jstor.org/stable/2677929.

Tietenberg, Tom. 2009. "Reflections- Energy Efficiency Policy: Pipe Dream or Pipeline to the Future." Review of Environmental Economics and Policy 3 (2): 304-20. http://dx.doi. org/10.1093/reep/rep004.

Tonn, Bruce, and Linda G. Berry. 1986. "Determinants of Participation in Home Energy Audit/ loan Programs: Discrete Choice Model Results.” Energy 11 (8): 785-95. http://dx.doi. org/10.1016/0360-5442(86)90017-4.

Train, Kenneth. 1985. “Discount Rates in Consumers' Energy-Related Decisions: A Review of the Literature." Energy 10 (12): 1243-53. http://dx.doi.org/10.1016/03605442(85)90135-5.

Trianni, A., and E. Cagno. 2012. "Dealing with Barriers to Energy Efficiency and SMEs: Some Empirical Evidences.” Energy 37 (1): 494-504. http://dx.doi.org/10.1016/j. energy.2011.11.005.

Turrentine, Thomas S., and Kenneth S. Kurani. 2007. “Car Buyers and Fuel Economy?” Energy Policy 35 (2): 1213-23. http://dx.doi.org/10.1016/j.enpol.2006.03.005.

Tversky, Amos, and Daniel Kahneman. 1981. "The Framing of Decisions and the Psychology of Choice." Science 211 (4481): 453-58. http://dx.doi.org/10.1126/science.7455683.

___ 1991. "Loss Aversion in Riskless Choice: A Reference-Dependent Model." Quarterly Journal of Economics 106 (4): 1039-61. http://dx.doi.org/10.2307/2937956.

—_ 1992. "Advances in Prospect Theory: Cumulative Representation of Uncertainty." Journal of Risk and Uncertainty 5 (4): 297-323. http://dx.doi.org/10.1007/BF00122574.

U.K. Department of Energy and Climate Change. 2013. Removing the Hassle Factor Associated with Loft Insulation: Results of a Behavioural Trial. London. https://www.gov.uk/ government/uploads/system/uploads/attachment data/file/236858/DECC loft clearance trial report final.pdf. 
Ungemach, C, Adrian R. Camilleri, E.J. Johnson, Richard P. Larrick, and Elke U. Weber. 2013. Translated Attributes as a Choice Architecture Tool: Trick and Treat. Summary of Working Paper. http://adriancamilleri.net/wp-content/uploads/Camilleri-et-al.-2013.-JPPMextended-abstract.pdf?770196.

U.S. Department of Energy. 1991. National Energy Strategy: Powerful Ideas for America. 1st ed. Washington D.C.: U.S. Department of Energy.

U.S. Environmental Protection Agency. 2015. “Learn About the New Label.” www. fueleconomy.gov/feg/label.

U.S. Environmental Protection Agency, and U.S. National Highway Traffic Safety Administration. 2011. "Greenhouse Gas Emissions Standards and Fuel Efficiency Standards for Medium- and Heavy-Duty Engines and Vehicles; Final Rule.” Federal Register 76 (179). http://www.gpo.gov/fdsys/pkg/FR-2011-09-15/pdf/2011-20740.pdf.

Verboven, Frank. 2002. "Quality-Based Price Discrimination and Tax Incidence: Evidence from Gasoline and Diesel Cars." RAND Journal of Economics 33 (2): 275-97. www.jstor.org/ stable/3087434.

Walls, Margaret, Karen L. Palmer, and Todd Gerarden. 2013. Is Energy Efficiency Capitalized into Home Prices? Evidence from Three US Cities. Discussion Paper 13-18. Washington, D.C.: Resources for the Future. http://www.rff.org/Publications/Pages/ PublicationDetails.aspx?PublicationID=22230.

Weber, Elke U., E. J. Johnson, K. F. Milch, H. Chang, J. C. Brodscholl, and D. G. Goldstein. 2007. "Asymmetric Discounting in Intertemporal Choice: A Query-Theory Account.” Psychological Science 18 (6): 516-23. http://dx.doi.org/10.1111/j.14672280.2007.01932.x.

Weber, Elke U., and Eric J. Johnson. 2009. "Mindful Judgment and Decision Making.” Annual Review of Psychology 60: 53-85. http://dx.doi.org/10.1146/annurev. psych.60.110707.163633.

Wood, Gavin, Rachel Ong, and Clinton McMurray. 2012. "Housing Tenure, Energy Consumption and the Split-Incentive Issue in Australia." International Journal of Housing Policy 12 (4): 439-69. http://dx.doi.org/10.1080/14616718.2012.730218.

Zivin, Joshua Graff, Matthew Kotchen, and Erin T. Mansur. 2012. Spatial and Temporal Heterogeneity of Marginal Emissions: Implications for Electric Cars and Other ElectricityShifting Policies. Working Paper 18462. National Bureau of Economic Research. http:// www.nber.org/papers/w18462. 


\begin{tabular}{|c|c|c|c|c|c|}
\hline \multicolumn{6}{|c|}{$\begin{array}{c}\text { Evaluating the Energy Efficiency Gap: A Research Workshop Conducted by: } \\
\text { Duke University Energy Initiative \& Harvard Environmental Economics Program } \\
\text { Supported by the Alfred P. Sloan Foundation } \\
\text { AGENDA }\end{array}$} \\
\hline Start & End & $\frac{\dot{y}}{\Sigma}$ & Speaker(s) & $\begin{array}{l}\text { Topic; questions from "framework for } \\
\text { understanding" }\end{array}$ & Question 2 \\
\hline \multicolumn{6}{|c|}{ DAY 1 (Thursday, October 24, 2013) } \\
\hline 9:00 AM & 9:45 AM & 45 & Newell; Stavins & Self introductions; framing presentations & \\
\hline \multicolumn{6}{|c|}{$\begin{array}{l}\text { 1. Are product market offerings and } \\
\text { pricing economically efficient? }\end{array}$} \\
\hline 9:45 AM & 10:00 AM & 15 & Busse & $\begin{array}{l}\text { 1.a) Are there too few EE alternatives, is } \\
\text { their EE too low, or are they priced too high } \\
\text { due to market power? }\end{array}$ & $\begin{array}{l}\text { 1.b) Are there too few new } \\
\text { EE offerings due to } \\
\text { consumer taste spillovers? }\end{array}$ \\
\hline $10: 00 \mathrm{AM}$ & 10:10 AM & 10 & Levinson & $\begin{array}{l}\text { 1.c) Do asymmetric information and/or } \\
\text { lemons problems inhibit EE? }\end{array}$ & \\
\hline $10: 10 \mathrm{AM}$ & 10:30 AM & 20 & & Response \& discussion & \\
\hline 10:30 AM & $10: 45$ AM & 15 & & Break & \\
\hline 10:45 AM & 11:00 AM & 15 & Gillingham & $\begin{array}{l}\text { 1.d) Are current prices of EE products too } \\
\text { high due to technology spillovers (R\&D and } \\
\text { LBD)? }\end{array}$ & $\begin{array}{l}\text { 1.e) Is there inadequate } \\
\text { consumer information on } \\
\text { available EE product } \\
\text { offerings? }\end{array}$ \\
\hline 11:00 AM & 11:30 AM & 30 & & Response \& open discussion & \\
\hline \multicolumn{6}{|c|}{$\begin{array}{l}\text { 2. Are energy operating costs inefficiently } \\
\text { priced and/or understood? }\end{array}$} \\
\hline 11:30 AM & 11:40 AM & 10 & Anderson & $\begin{array}{l}\text { 2.a) Are gasoline prices too low due to } \\
\text { unpriced externalities? }\end{array}$ & \\
\hline 11:40 AM & 11:50 AM & 10 & Palmer & $\begin{array}{l}\text { 2.b) Are electricity prices too low due to } \\
\text { unpriced externalities? }\end{array}$ & \\
\hline 11:50 AM & 12:05 PM & 15 & & Response \& discussion & \\
\hline 12:05 PM & 12:50 PM & 45 & & Lunch & \\
\hline $12: 50 \mathrm{PM}$ & 1:00 PM & 10 & Wolfram & $\begin{array}{l}\text { 2.c) Are electricity prices too low due to } \\
\text { regulation? }\end{array}$ & \\
\hline 1:00 PM & 1:15 PM & 15 & & Response \& discussion & \\
\hline 1:15 PM & 1:25 PM & 10 & Sallee & $\begin{array}{l}\text { 2.d) Are beliefs about current and future } \\
\text { fuel prices and/or usage systematically } \\
\text { uninformed or biased downward? }\end{array}$ & \\
\hline
\end{tabular}




\begin{tabular}{|c|c|c|c|c|c|}
\hline Start & End & $\frac{\dot{m}}{\Sigma}$ & Speaker(s) & $\begin{array}{l}\text { Topic; questions from "framework for } \\
\text { understanding" }\end{array}$ & Question 2 \\
\hline \multicolumn{6}{|c|}{ DAY 1 (cont.) } \\
\hline 1:25 PM & 1:35 PM & 10 & Rapson & $\begin{array}{l}\text { 2.e) Are beliefs about current and future } \\
\text { electricity prices and/or usage } \\
\text { systematically uninformed or biased } \\
\text { downward? }\end{array}$ & \\
\hline 1:35 PM & 1:50 PM & 15 & & Response \& discussion & \\
\hline 1:50 PM & 2:05 PM & 15 & Fowlie & $\begin{array}{l}\text { 2.f) Do EE analysts systematically } \\
\text { overestimate energy savings from EE? }\end{array}$ & $\begin{array}{l}\text { 2.g) Do EE analysts take } \\
\text { insufficient account of } \\
\text { heterogeneity in EE savings, } \\
\text { resulting in overstating the } \\
\text { average benefits of EE? }\end{array}$ \\
\hline 2:05 PM & 2:45 PM & 40 & & Response \& open discussion & \\
\hline 2:45 PM & 3:00 PM & 15 & & Break & \\
\hline \multicolumn{6}{|c|}{$\begin{array}{l}\text { 4. Do other costs inhibit more energy- } \\
\text { efficient decisions? }\end{array}$} \\
\hline 3:00 PM & 3:15 PM & 15 & Houde & $\begin{array}{l}\text { 4.a) Do EE analysts take sufficient account of } \\
\text { product attributes that are inferior for EE } \\
\text { products? }\end{array}$ & $\begin{array}{l}\text { 4.b) Do EE analysts take } \\
\text { sufficient account of other } \\
\text { costs of implementing EE } \\
\text { options? }\end{array}$ \\
\hline 3:15 PM & $3: 45$ PM & 30 & & Response \& open discussion & \\
\hline \multicolumn{6}{|c|}{$\begin{array}{l}\text { 3. Are product choices cost-minimizing in } \\
\text { present-value terms? }\end{array}$} \\
\hline 3:45 PM & 3:55 PM & 10 & Davis & $\begin{array}{l}\text { 3.a) Do split incentives/agency issues inhibit } \\
\text { more energy-efficient decisions? }\end{array}$ & \\
\hline 3:55 PM & 4:05 PM & 10 & Aufhammer & $\begin{array}{l}\text { 3.b) Does learning-by-using inhibit more } \\
\text { energy-efficient decisions? }\end{array}$ & \\
\hline 4:05 PM & 4:20 PM & 15 & & Response \& discussion & \\
\hline 4:20 PM & 4:30 PM & 10 & Pindyck & $\begin{array}{l}\text { 3.h) Do EE analysts use discount rates that } \\
\text { are on average too low, given heterogeneity } \\
\text { in discount rates across consumers? }\end{array}$ & \\
\hline 4:30 PM & 5:00 PM & 30 & & Response \& discussion & \\
\hline 6:30 PM & 9:00 PM & & & Reception and dinner; Le Meridien Hotel & \\
\hline
\end{tabular}




\begin{tabular}{|c|c|c|c|c|c|}
\hline Start & End & $\frac{\dot{m}}{\Sigma}$ & Speaker(s) & $\begin{array}{l}\text { Topic; questions from "framework for } \\
\text { understanding" }\end{array}$ & Question 2 \\
\hline \multicolumn{6}{|c|}{ DAY 2 (Friday, October 25, 2013) } \\
\hline 8:30 AM & 8:45 AM & 15 & Newell; Stavins & Intro remarks; summary of previous day & \\
\hline \multicolumn{6}{|c|}{$\begin{array}{l}\text { 3. Are product choices cost-minimizing in } \\
\text { present-value terms? (cont.) }\end{array}$} \\
\hline $8: 45$ AM & 9:00 AM & 15 & Metcalf & $\begin{array}{l}\text { 3.i) To what extent can option value (due to } \\
\text { uncertainty or technological change) affect } \\
\text { EE decisions? Is this taken into account by EE } \\
\text { analysts? }\end{array}$ & $\begin{array}{l}\text { 3.j) To what extent can } \\
\text { systematic risk affect } \\
\text { energy-efficient decisions? } \\
\text { Is this taken into account by } \\
\text { energy-efficient analysts? }\end{array}$ \\
\hline 9:00 AM & 9:15 AM & 15 & & Response \& discussion & \\
\hline 9:15 AM & 9:45 AM & 30 & $\begin{array}{l}\text { Allcott; } \\
\text { Larrick }\end{array}$ & $\begin{array}{l}\text { 3.c) Does inattention to and/or a lack } \\
\text { salience of energy use/operating costs } \\
\text { inhibit more energy-efficient decisions? }\end{array}$ & $\begin{array}{l}\text { 3.d) Do issues with loss- } \\
\text { aversion or reference points } \\
\text { inhibit more energy- } \\
\text { efficient decisions? }\end{array}$ \\
\hline 9:45 AM & 9:55 AM & 10 & $\begin{array}{l}\text { Allcott; } \\
\text { Larrick }\end{array}$ & $\begin{array}{l}\text { 3.e) Does heuristic decision making and/or } \\
\text { bounded rationality inhibit more energy- } \\
\text { efficient decisions? }\end{array}$ & \\
\hline 9:55 AM & $10: 15$ AM & 20 & & Response \& discussion & \\
\hline 10:15 AM & 10:30 AM & 15 & & Break & \\
\hline 10:30 AM & $11: 00 \mathrm{AM}$ & 30 & $\begin{array}{l}\text { Knittel (3.f-g); } \\
\text { Weber (3.f) }\end{array}$ & $\begin{array}{l}\text { 3.f) Does myopia/short-sightedness inhibit } \\
\text { more energy-efficient decisions? }\end{array}$ & $\begin{array}{l}\text { 3.g) To what degree do } \\
\text { capital market } \\
\text { failures/liquidity constraints } \\
\text { influence consumer } \\
\text { discount rates? }\end{array}$ \\
\hline 11:00 AM & 12:00 PM & 60 & & Response \& final discussion & \\
\hline
\end{tabular}

